\title{
Who Runs the International System? Power and the Staffing of the United Nations Secretariat
}

\section{Citation}

Novosad, Paul, and Eric Werker. "Who Runs the International System? Power and the Staffing of the United Nations Secretariat." Harvard Business School Working Paper, No. 15-018, September 2014.

\section{Permanent link}

http://nrs.harvard.edu/urn-3:HUL.InstRepos:13360008

\section{Terms of Use}

This article was downloaded from Harvard University's DASH repository, and is made available under the terms and conditions applicable to Open Access Policy Articles, as set forth at http:// nrs.harvard.edu/urn-3:HUL.InstRepos:dash.current.terms-of-use\#OAP

\section{Share Your Story}

The Harvard community has made this article openly available.

Please share how this access benefits you. Submit a story.

Accessibility 
H A R VAR D

\section{Who Runs the International System? Power and the Staffing of the United Nations Secretariat}

Paul Novosad

Eric Werker

\section{Working Paper}

15-018

August 30, 2014 


\title{
Who Runs the International System? Power and the Staffing of the United Nations Secretariat \\ $*$
}

\author{
Paul Novosad ${ }^{\dagger}$
}

Eric Werker

August 2014

\begin{abstract}
National governments frequently pull strings to get their citizens appointed to senior positions in international institutions. We examine, over a 60 year period, the nationalities of the most senior positions in the United Nations Secretariat, ostensibly the world's most representative international institution. The results indicate which nations are successful in this zero-sum game, and what national characteristics correlate with power in international institutions. The most overrepresented countries are small, rich democracies like the Nordic countries. Statistically, democracy, investment in diplomacy, and economic/military power are predictors of senior positions - even after controlling for the U.N. staffing mandate of competence and integrity. National control over the United Nations is remarkably sticky; however the influence of the United States has diminished as U.S. ideology has shifted away from its early allies. In spite of the decline in U.S. influence, the Secretariat remains pro-American relative to the world at large.
\end{abstract}

${ }^{*}$ We are grateful to Uggi Lee, Daniel Lim, Vikram Viswanathan, and Edward Zhong for diligent research assistance. Kristy Buzard, Michael Clemens, Christina Davis, Jeff Friedman, Julia Gray, Diego Hernandez, Tana Johnson, Peter Katzenstein, Michael Levi, Beth Simmons, Ian Tomb, several staff members of the United Nations, and in particular Ilyana Kuziemko provided helpful input, comments and suggestions, as did seminar participants at Columbia University, the Political Economy of International Organizations conference at Princeton and the Economics of National Security meeting at NBER. The first stage of data gathering for this project was funded by the National Bureau of Economic Research's Economics of National Security program to Kuziemko and Werker, and Werker thanks the Harvard Business School Division of Research and Faculty Development for continuing support. The usual disclaimer applies.

${ }^{\dagger}$ Dartmouth College

${ }^{\ddagger}$ Harvard Business School 


\section{Introduction}

This paper examines the nationality of the most senior officials in the United Nations Secretariat over the last sixty years, with the goal of understanding which nations have been successful in controlling this institution, and what factors have allowed them to do so. There is intense competition among nations over the staffing of these positions, and once in these positions, there is evidence that officials act in the interests of their home nations.

Because of the contested nature and scarcity of these positions, Secretariat staffing data can be used to inform at least two significant discussions. The most direct application is to understand who runs the United Nations itself. While the United Nations is arguably the world's most representative international organization, it was set up by a particular set of nations, the victors of the second world war, with the goal of sustaining a certain kind of world order. Our staff nationality data provide a time-varying proxy for the importance of each nation at the United Nations. Our results suggest that the post-war balance of control at the United Nations has been largely sustained, in spite of significant changes in the balance of global economic power over this time.

A second application is to treat the staffing of international institutions as an outcome of the distribution of power across nations. According to John Mearsheimer, realists maintain that international institutions are "basically a reflection of the distribution of power in the world" (1994). There is a substantial literature on the measurement of power (Nye, 2011b), and a vigorous debate on whether power is even measurable (Guzzini, 2013). By identifying the distribution of positions in the Secretariat, we provide an objective measure across all nations of a zero-sum dimension of power, the power to control international institutions (Bachrach and Baratz, 1962; Barnett and Duvall, 2005), that appears to be of significant concern to governments around the world. This method of comparing power across nations addresses some of the critiques in the literature on the empirical measurement of power, 
particularly the critique that a focus on military capability is too narrow in scope. Our approach therefore brings together two traditions of scholarship that are usually seen as incongruent: the measurement of power, and the treatment of power as multidimensional.

The Secretariat is staffed by nationals of the United Nations' 193 member states. In theory, the Secretariat is to be staffed according to the competence and integrity of individual candidates, with an additional mandate of achieving broad representation of nations, but in practice the top positions are highly contested in an intensely political process. The struggle for influence over the appointment of the most recent Secretary General, Ban Ki-Moon, was widely covered, with China's growing global influence an important factor in the selection of a candidate from Asia (Thant and Scott, 2007). Ban's appointed top management team was, according to the Financial Times, "dominated by officials from powerful countries" (2007). Among them was then-U.S. ambassador to Indonesia Lynn Pascoe who was to head the political affairs department despite other countries' objections that he was "a State Department guy" (Turner, 2007). Three years later, when Briton and former Blair cabinet member Valerie Amos was appointed under-secretary general for humanitarian affairs, a source to the Guardian newspaper observed: "This is a massively significant job, one of the top five at the U.N. [...] It would be unthinkable for Britain not to have one of the top five jobs" (Watt, 2010). Competition over other high-level positions occurs blatantly as governments support the candidacy of their own nationals (The Economist, 1989).

Once secure in their position, staff have the ability to influence affairs in the interests of their home nation. The United Nations reported in its own newsletter, "The United Nations has increasingly become a political arena where high officials engage in political give-andtake and where 'interest groups' lobby for their country's interests... Political appointees are frequently not loyal to the United Nations, but to their respective governments, upon which they depend for further reward or punishment" (Finger and Hanan, 1980). Informal spheres of national control appear to be a feature of many international institutions, including the 
European Commission and NATO (Kleine, 2013), and increasing evidence suggests that the national identities of bureaucrats affect the decision-making of institutions (Kaja and Werker, 2010; Johns, 2007).

We assembled data on the most senior positions in the Secretariat (approximately 80 out of some 43,000 total staff members today, United Nations 2012), as published in the U.N. Yearbook from 1947-2007. We researched the nationalities of these senior officials to generate time series data on the countries controlling the executive arm of the United Nations. This dataset allows us to analyze how positions are allocated, and to use the allocation of positions as a window into the influence, or power, of states in the international system.

We introduce the notion of "excess representation" in the Secretariat, which is the number of senior Secretariat positions held by a country, over and above what would be expected if positions were held in proportion to countries' populations. Ranking countries by excess representation, we find that the top positions are dominated by rich democracies: the five most overrepresented countries in the Secretariat are Sweden, Norway, Finland, New Zealand, and Ireland. The United States is overrepresented, and China is significantly underrepresented.

We then test for the factors that predict a country's representation in the Secretariat. We first model the staffing mandate of the United Nations, which requires staff to be selected on criteria of competence and integrity, with some regard for equal geographical distribution. We proxy competence with the national stock of university graduates and integrity with a measure of freedom from corruption. Both variables are significant predictors in the expected direction, as is the assessment of dues to the United Nations. We next examine additional factors, including total GDP, per capita wealth, military spending, investment in diplomacy, and democracy. With the inclusion of these additional variables, we find that diplomacy, wealth, GDP and democracy are all significant predictors of influence. ${ }^{1}$ The most robust of

\footnotetext{
${ }^{1}$ As we describe in the results, it is difficult to disentangle military expenditure, human capital, assessment of dues to the United Nations and GDP, because they are so highly correlated with each other. We report this result as GDP not because we think GDP is a more important factor than the other three, but because
} 
these is diplomacy, suggesting that countries can invest in institutional power in a manner that is at least partially orthogonal to military investment and economic power. Conditional on that investment, rich countries and democracies are more successful in exerting their power overseas.

We extend our method to take alliances between nations into account. If two countries have similar preferences over international policies, they may benefit from having each other in powerful positions. In order to capture the direct and indirect power (i.e. power held by allies) of a country, we construct a measure of national influence that takes into account the similarity of preferences to other influential nations, as proxied by similarity of U.N. General Assembly voting records (Gartzke, 1998). ${ }^{2}$

Finally, we use these measures to describe the influence of the United States in the Secretariat over the last 60 years. We find that the share of Americans in senior positions has been declining since the 1960s. These senior positions have not been replaced by growing middle income countries, but by citizens of other rich democracies. While the world population share of Western Europe and its offshoots fell from 18\% in 1965 to $13 \%$ in 2005, their share of Secretariat positions remained largely constant, falling from $46 \%$ in 1965 only to $45 \%$ in 2005.

If American and European ideologies were the same as they were in 1950, the United States would not have experienced any real loss of influence at the Secretariat, as its lost positions were taken up by its 1950 allies. However, by our measures, the ideologies of the United States and its 1950 allies have diverged, especially since the 1980s, so the placement of old allies in former U.S. positions has led to a substantial loss in American influence at the United Nations.

These findings both reinforce and add nuance to Keohane's 1984 notion that international

it is the most commonly used proxy for the large set of indicators highly correlated with GDP.

${ }^{2}$ The methodology supports measures of alliance other than voting affinity, such as common membership in intergovernmental organizations. The latter yields broadly similar results in our applications. 
institutions can outlast the circumstances determining their creation. The United Nations Secretariat continues to reflect the membership of the U.S.-led alliance that was instrumental in its creation, in spite of that alliance's declining economic and military dominance of the world. But it no longer represents American ideology; American control over the United Nations is now constrained by the allies with which it built the institution.

These findings - as well as the broader methodology of measuring the outcome of diplomatic struggle by looking at staffing outcomes - contribute to the extensive literature on power in international relations (reviewed in Baldwin 2013).

The search for objective measures of power that were comparable across nations goes back at least to the eighteenth century (Gulick 1955, cited in Baldwin 2013). These capabilitybased measures became ever more complex, as reflected in Morgenthau (1948), culminating in Cline's formula (1975), which was a nonlinear combination of population, territory, income, energy, minerals, manufacturing, food, trade, as well as strategy and will. Cline's measure was used by the U.S. army among others to estimate long run trends in national capabilities (Tellis et al., 2000).

The capability-based approach has been critiqued by scholars across a number of disciplines, who argue that power is situationally specific and relational and therefore "not objectively measurable" (Guzzini, 2009). Contrary to the analysts who count national manpower and resources, Guzzini argues that power is not fungible; what generates power in one context may not generate power in another. For example, U.S. military resources may not be usable against friends as they would be against enemies.

A key development in this literature over the last half century has been the description and categorization of different types of power, including the well-known "faces of power" debate. Dahl's 1957 seminal study defined a notion of compulsory power as the ability of A to get B to do what B otherwise would not do. Bachrach and Baratz (1962) argued that there was a second face of power: the ability to set the agenda. Lukes (1974) added 
a third face: the ability to influence others' initial preferences. More recently, Barnett and Duvall (2005)'s typology suggests four faces of power. While the traditional capabilitybased approach is well captured by the idea of compulsory power, control over the staffing of international institutions is closer to Barnett and Duval's Institutional and Productive Powers: first, the ability to control actors through their diffuse interactions in institutions, and second, the ability to influence "systems of knowledge and discursive practices of broad and general social scope" (Barnett and Duvall, 2005), a fair description of the Secretariat's global agenda-setting role.

With reference to Guzzini (2009), the extent to which an institution like the United Nations shapes the capabilities of nations at all is in itself an outcome of the distribution of state power; while our paper does not directly address this aspect of power, the distribution of influence within the United Nations remains an important arena of struggle, even if it takes place within a particular structural context that is also of interest.

Analyzing U.N. Secretariat positions may appear similar to the largely realist approach of ranking states according to their ability to exert compulsory power. However, the association in the literature between empirical measures of power and the focus on compulsory power is largely due to the absence of appropriate empirical measures for other dimensions of power. Multidimensional thinking about power does not obviate the value of measurement, so long as our outcome is defined clearly.

Our scope is narrow. We focus on the realization of a single dimension of state power: power in international institutions. We cannot predict whether one nation can exert power over another in a general sense (e.g. in a war), and our measure is only relevant to the extent that control over international institutions is perceived by nations as being important.

With that qualification, our method has several desirable characteristics. First, we are measuring a global outcome that involves nearly all countries in the world, measured with equal accuracy for all countries. Second, it is a continuous measure, available each year 
that we observe the senior staff positions in the Secretariat, allowing us to observe changes over time. These features give researchers a new opportunity to study the expression of an arguably increasingly important dimension of power in a panel data setting.

The main weakness of Secretariat representation as a measure of power is that countries do not equally value the United Nations, so some will exert less effort to secure senior positions in the organization. While the Secretariat is one of the most representative and central institutions of the international system, it is clearly not the case that every country puts in the same level of resources to get staff into key positions. The measure is therefore a combination of the desire and the ability to influence international outcomes. Nevertheless, countries that can obtain these positions at a lower cost can be considered more powerful (Harsanyi 1962, cited in Baldwin 2013), and they are likely to obtain more positions, all other things equal. ${ }^{3}$

Besides the work on the United Nations and on power, this paper contributes to several different literatures. One is the study of how individual nations exert influence within international institutions (Robert and Jacobson, 1973). Much of the recent work in this field focuses on the role of major powers in shaping outcomes including loans, agendas, concessions, votes, or peacekeeping scope (Allen and Yuen, 2013; Kaja and Werker, 2010; Kilby, 2011; Kleine, 2013; Kuziemko and Werker, 2006; Lim and Vreeland, 2013; Stone, 2004). A small but growing area of literature takes advantage of the unique institutional environment of the United Nations to answer broader questions (Gartzke, 1998; Fisman and Miguel, 2007). Finally, there is a literature on international bureaucrats (e.g. Johns 2007, Urpelainen 2012, Johnson 2013) that has little direct crossover with this paper, but reinforces the notion that

\footnotetext{
${ }^{3}$ Independent of the preferences of governments, nationals of different countries may have different preferences regarding the desirability of UN Secretariat positions. While this could be a driver of staff composition, it would not affect the fact that these countries would then have an outsize influence at the UN as a result of the preferences of their nationals. In fact, we would expect preferences of citizens toward influencing the UN to be correlated with the preferences of their elected governments. Finally, this effect would go in the opposite direction of our findings on wealth, because citizens of poor countries would likely value a secure and well-remunerated UN position more highly than citizens of rich countries.
} 
international bureaucrats retain allegiance to their home countries.

The rest of the paper is organized as follows. Section 2 describes what the Secretariat

does and how it is staffed. Section 3 explains the Secretariat position data and the empirical specification. Section 4 reports results on the determinants of representation in the Secretariat and the countries that are most overrepresented. Section 5 examines alliances, and applies our methodology to the case of the United States. Section 6 concludes.

\section{Political Economy of the United Nations Secretariat}

\subsection{What does the Secretariat do?}

The United Nations is the primary international organization responsible for maintaining peace and facilitating cooperation among nations to resolve issues that require collective action. The United Nations' executive arm is the Secretariat, and it plays a key role in agenda-setting for the various deliberative U.N. organs, as well as managing global peacekeeping operations. The Secretariat also houses the U.N. Department of Political Affairs, which is essentially a ministry of foreign affairs with active policy around the world.

The United Nations is organized into six major organs: (i) the General Assembly; (ii) the Security Council; (iii) the Economic and Social Council; (iv) the defunct Trusteeship Council; (v) the International Court of Justice; and (vi) the Secretariat. The U.N. Secretariat is the executive arm of the United Nations. It serves the other bodies of the U.N., administers operations initiated by those bodies, conducts surveys and research, and communicates with non-state actors such as media and non-government organizations.

While the decision-making powers of the U.N. reside within its deliberative bodies (the General Assembly, Economic and Social Council, and Security Council), the Secretariat plays a key role in implementation and in setting the agenda for those bodies. The content of the resolutions debated in the deliberative bodies originates in the Secretariat, and many 
of the programs are implemented by organs of the Secretariat. The Secretariat is the main source of economic and political analysis for the General Assembly and Security Council, and operates political field missions which provide knowledge to those bodies.

The Secretariat prepares the technical assessments that precede peacekeeping operations and appoints the leaders of peacekeeping operations. These Heads of Mission report directly to an under-secretary general in the Secretariat, and the deliberative bodies have no further role in implementation of peacekeeping operations.

Given this range of roles, the Secretariat has more decision-making power than its de jure status as a "member to serve the other organs" suggests. In a 1955 address, Secretary General Dag Hammerskjold described this power as follows:

The United Nations is what member nations made it, but within the limits set by government action and government cooperation, much depends on what the Secretariat makes it... [it] has creative capacity. It can introduce new ideas. It can, in proper forms, take initiatives. It can put before member governments findings which will influence their actions (Kelen, 1968). ${ }^{4}$

The staff of the Secretariat are ostensibly international civil servants who serve the goals of the United Nations rather than their home countries. However, the spoken and unspoken struggle between nations to place their nationals in senior positions at the United Nations speaks both to the importance of this creative power of the Secretariat, as well as the widespread belief that Secretariat staff continue to favor the interests of their home nations.

\footnotetext{
${ }^{4}$ Many were troubled by this normative view of the Secretariat, and perceived Hammerskjold as too activist a Secretary General; upon his death, he was replaced by U Thant who was expected to guide the Secretariat to a more subdued role. The case serves to demonstrate that nations place significant importance on the behavior and composition of the U.N. Secretariat.
} 


\subsection{Staffing the Secretariat}

\subsubsection{Official Procedures}

The Secretary General (SG) heads the United Nations Secretariat, and is selected by the Security Council, with approval from the General Assembly. The next layer of hierarchy consists of under-secretaries general, who are largely selected by the SG and then appointed if approved by the General Assembly. The General Assembly also plays a significant role in determining the number and sphere of influence of under-secretaries. The remaining approximately 43,000 staff of the Secretariat are appointed by senior Secretariat officials without direct interaction with the deliberative bodies (Wynes and Zahran, 2011).

Appointment of Secretariat officials is guided by two criteria stated in the Charter of the United Nations:

The paramount consideration in the employment of the staff and in the determination of the conditions of service shall be the necessity of securing the highest standards of efficiency, competence, and integrity. Due regard shall be paid to the importance of recruiting the staff on as wide a geographical basis as possible (United Nations, 1945).

Since 1958, internal documents discussed a "desirable range" of staff that should come from each country, a range which would be based on membership (i.e. some minimum number of positions per country), population, and assessment of dues, with the largest weight on assessment. ${ }^{5,6}$ These desirable ranges apply to the total stock of positions and do not consider seniority; in practice, it has been observed that the nationality distribution of senior positions

\footnotetext{
${ }^{5}$ From about 1960 to 1975 , the relative target weights on membership, population and assessment were $20 \%, 9 \%, 71 \%$. The formula has changed several times since then; current documents suggest respective weights of $40 \%, 5 \%$ and $55 \%$.

${ }^{6}$ Membership dues owed by members of the United Nations are proportional to their GDP, with a progressive ceiling to lower the cost of membership to poor nations and limit one nation (the United States) from paying too large a share. Many nations have failed to pay their full dues at various times; staffing formulae are based on assessment, not on actual dues paid.
} 
departs more significantly from the desirable range than the distribution of all positions, a situation which the General Assembly has on occasion discussed (Meron, 1982).

\subsubsection{Unofficial Jockeying}

It is widely recognized that nations lobby to place their staff in senior positions in the Secretariat. Indeed, there is a 600-page book on the subject, titled Politics of Staffing the United Nations Secretariat (Ameri, 1996). ${ }^{7}$ The appointment of Secretaries General, which takes place approximately every ten years, is watched carefully by international analysts. The selection of under-secretaries was an important arena of conflict in the Cold War, and frequently discussed in the General Assembly, with Soviets pushing for a transparent division of powers with three under-secretaries representing respectively the Western Block, the Eastern Block and the Non-aligned countries (Reymond, 1967). Such a division would make more explicit the allegiance that Secretariat staff often retained to their home countries.

The U.S. Senate Select Committee on Intelligence routinely published a report entitled, "Soviet Presence in the U.N. Secretariat," (United States Senate, 1985) which claimed,

Soviets in the Secretariat function reasonably well as adjuncts of the Soviet Foreign Ministry and intelligence services [...] The 800 Soviets assigned to the United Nations as international civil servants report directly to the Soviet missions and are part of an organization managed by the Soviet Foreign Ministry, intelligence services, and the Central Committee of the Communist Party. [... They] are involved in shaping conference papers, controlling the flow of news to staff and delegations, influencing delegations seeking Secretariat advice, and aiding Soviet diplomats during conference and other deliberations. [...] Approximately one fourth of the Soviets in the U.N. Secretariat are intelligence officers and many more are co-opted by the KGB.

\footnotetext{
${ }^{7}$ Additional references include Finger (1980) and Reymond (1967).
} 
The Committee Report implies that the United States did not exert the same measure of control over Americans at the United Nations; nevertheless the importance of placing nationals of aligned countries in senior positions is evident.

\section{Data and Specifications}

\subsection{Constructing the Database of Secretariat Positions}

We compiled data on Secretariat staffing from the annual Yearbook of the United Nations, which summarizes the annual activities of all the organs of the U.N., and was published from 1947 to 2007. ${ }^{8}$ The Appendix of the U.N. Yearbook lists the names and titles of the most senior staff in the Secretariat and Specialized Agencies, beginning with the Secretary General. The number of Secretariat positions listed in a given year ranges from 26 in 1950 to just over 100 in 2000.

Using the name and position of each person listed, we researched their nationality, drawing on directories (such as Who's Who in the United Nations, 1975; 1992; 1951), media articles and other historical documents. Figure 1 displays the number of positions listed over time, along with the number of those positions for which we were able to verify the nationality of the position-holder. ${ }^{9}$

[Figure 1 about here.]

To verify that our list accurately captured the most senior positions in the Secretariat of the United Nations, and to rank the positions in terms of importance, we hired two independent experts on the United Nations. ${ }^{10}$ Both experts confirmed that our list did not

\footnotetext{
${ }^{8}$ The last available copy of this publication is from 2007. It is not clear whether more recent editions are still forthcoming or whether the United Nations has ceased publication of annual yearbooks.

${ }^{9}$ The rise in positions from 1950 to 1980 is likely influenced by a growth in the scope of the United Nations. However, the decline in positions listed after 2000 likely represents an editorial choice to list fewer positions, given that the size or scope of the United Nations did not change significantly in this period.

${ }^{10}$ Each expert had decades of experience in the U.N. system, and preferred to remain anonymous given the potential political sensitivity of this study.
} 
have significant lacunae, and independently assigned each position a weight on a scale of 1 to 6 reflecting the relative importance of that position. The Secretaries General were assigned a ranking of 6 , the under-secretaries were assigned 5 , and so on. Using the mean importance rank of the two experts, we created a second measure of Secretariat representation, which is the share of positions held by each nation in a given year, weighted by the importance of each position held. We rescaled this measure so that it sums to one in each year.

We added several other country-year variables: (i) GDP, population and overseas development assistance (World Development Indicators, Penn World Tables); (ii) stock of people with tertiary education (Barro and Lee, 2012); (iii) the Worldwide Governance Indicators (of which freedom from corruption is a component) (Kaufmann et al., 2011); (iv) the Combined Polity Score measure of democracy from the Polity IV database (Marshall and Jaggers, 2002); (v) state military expenditure and the Composite Index of National Capability from Correlates of War v. 3.0 (Singer, 1987); and (vi) an annual count of the number of foreign embassies operated by each country as a measure of national investment in international diplomacy (the Diplomatic Contacts database from Rhamey et al. (2010)). Finally, we calculated assessments of dues to the United Nations using data on national GDP, population, U.N. membership and the formulae described in Section 2.2.1.

The governance measure is missing data before 1994, so we impute backward from the earliest available year to avoid dropping a large number of observations when we include this variable. Results on corruption are therefore more relevant in the cross section than in the time series.

[Table 1 about here.]

Table 1 displays summary statistics of all measures used. 


\subsection{Measuring Representation}

\subsubsection{Measuring Excess Representation}

We define a country's raw representation as the share of Secretariat positions held by that country's nationals. We consider an alternate measure that weights each position by the expert assessment of its importance. We define excess representation as the ratio of a nation's raw representation to its share of world population in a given year. Our reference point is thus a notion of the United Nations as a kind of global democracy, with each person in the world equally represented. If representation were "equal" in this sense, then China and India would together control more than a third of the positions in the Secretariat, and the measure of excess representation would be one for all countries.

\subsubsection{The Staffing Mandate of the United Nations and Other Factors Influenc- ing Representation}

Two anecdotes from the early years of the United Nations (both from Ameri 1996) highlight the challenges of achieving fair geographic coverage of top officials. In the early years of the United Nations, citizens of the United States held a disproportionate share of positions in the Secretariat - from 20-25\% of all senior positions in the 1950s. A factor contributing to this was that the location of headquarters in New York made it far more difficult to recruit nationals of other countries. ${ }^{11}$

A second widely observed anecdote in early staffing decisions was that many nations had a scarcity of individuals with sufficient education and experience to able to fill a senior position at the United Nations. Governments were often invited to recommend their nationals for senior positions, but declined to do so on the grounds that they did not have capable staff

\footnotetext{
${ }^{11}$ It would be incorrect to view this as a historical accident; the locating of U.N. headquarters in New York occurred because of the United States' position as the dominant world power; the location of main offices of U.N. agencies is one way in which nations exert influence over the organization.
} 
to spare.

The main criteria for staff selection, as inscribed in the Charter, are "efficiency, competence, and integrity," with an equitable geographic distribution being a secondary factor. Our data do not allow us to see the caliber of individual bureaucrats in the Secretariat. However, we can to some extent control for the pool of available candidates from each country with country-level measures that proxy for the staff selection criteria. To proxy for efficiency and competence, we use a measure of human capital, or the number of people with tertiary education (often a prerequisite for employment at the United Nations). To proxy for integrity, we use the freedom from corruption measure from the Worldwide Governance Indicators (Kaufmann et al., 2011). The latter is motivated by Fisman and Miguel (2007), who found that U.N. diplomats' law abidance in New York was correlated with the corruption level in their home countries. Finally, we include the assessment of dues, given its key role in the desirable representation formulae.

Our model takes the form:

$$
Y_{i t}=\beta_{0}+\beta_{1} * \text { POPULATION } N_{i t}+\beta_{2} * E D U C_{i t}+\beta_{3} * C O R R U P T I O N_{i t}+\beta_{4} * D U E S_{i t}+\zeta X_{i t}+\epsilon_{i t}
$$

Where $Y_{i t}$ is a measure of representation, POPULATION, EDUC, CORRUPTION and $D U E S$ reflect the staffing mandate of the United Nations, and $X_{i t}$ is a vector of additional factors that we would like to test, which are wealth (GDP per capita), traditional international power (military spending), diplomacy (as proxied by the number of embassies run by countries), and democracy.

A desirable empirical specification should have two main characteristics. First, all predictive factors should be treated as zero sum, since the share of Secretariat positions is also zero sum. In other words, increasing a country's population by $10 \%$ should not affect our prediction of that country's representation if the population of all other countries has also increased by the same $10 \%$. To achieve this, we rescale all observations on Secre- 
tariat positions, population, assessments of dues, human capital stock, military spending and diplomatic contacts to convert these to shares of the world total of each value. For instance, instead of gross military spending, we use share of global military spending. The remaining variables (democracy, freedom from corruption, GDP per capita) do not have a notion of a "global total;" to make these zero sum, we rescale them so that observations each year have a mean of zero and a standard deviation of one. Table 1 shows descriptive statistics of both untransformed and transformed variables.

Second, we need to control for the fact that many of the national variables we describe exhibit significant serial correlation, as do positions in the Secretariat, since they are often held for multiple years. To avoid overcounting highly similar observations, we cluster our standard errors by country in our time series regressions, and by decade in our country fixed effect regressions.

\section{Who Runs the United Nations?}

\subsection{Descriptive Statistics}

Figure 2 shows the excess representation of the United States, Germany, Russia, China, and Japan. As discussed above, the United States had a disproportionate share of positions at the inception of the United Nations, a share which fell significantly but then stabilized in the 1980s. Japan and Germany had little representation following the end of the second world war, but have steadily risen in prominence, surpassing the United States in excess representation by the 1980s. ${ }^{12}$ The Soviet Union was almost never overrepresented at the United Nations, in part because of Stalin's significant efforts to undermine the institution in the early years (Finger, 1975). The fall of the Soviet Union led to a further drop in

\footnotetext{
${ }^{12}$ This timing coincides with Japan's "internationalization" policies during the Nakasone administration, which aimed to increase Japan's role in global affairs (George, 1993).
} 
Russia's influence in the Secretariat. China has been and continues to be dramatically underrepresented in the U.N. Secretariat - with an average over all years of only $1 \%$ of senior positions in the Secretariat.

[Figure 2 about here.]

Figure 3 shows the world population share and share of U.N. Secretariat positions of the Western European powers and their offshoots Canada, the United States, New Zealand, and Australia. While the Western countries' share of world population and GDP have been steadily declining since the 1960s, their control over the U.N. Secretariat has been largely unmitigated; in 2007 they continued to hold $45 \%$ of Secretariat positions, while their world population share has fallen from $18 \%$ to $12 \%$. This graph shows that in spite of the widely discussed rise to international prominence of middle income nations like the BRICs, Western Europe and its offshoots have not lost control over this key U.N. body.

[Figure 3 about here.]

Figure 4 displays scatterplots of the share of positions in the Secretariat against log population and $\log$ assessment. ${ }^{13}$ There is a clear upward sloping relationship in both graphs, but many countries are far from the 45 degree line. The $R^{2}$ measure for the regression of Secretariat share on population share is 0.11 , while for representation on assessment of dues it is 0.70 . In the bivariate analysis, payment of dues appears to be a much better indicator of power in the Secretariat than population.

[Figure 4 about here.]

Table 2 presents excess representation in the Secretariat, by country, averaged over all years. ${ }^{14}$ Excess representation is defined as the ratio of a country's share of Secretariat positions to its share of world population, and is proportional to a country's vertical distance

\footnotetext{
${ }^{13}$ We use logs on the $\mathrm{X}$ axis to display small and large countries on the same graph. We must then use a $\log$ scale for the $\mathrm{Y}$ axis in order for the 45 degree line (which indicates a notion of "equal" representation) to be straight.

${ }^{14}$ Appendix Table A1 lists countries ranked by their total number of senior Secretariat positions, without taking population into account.
} 
from the 45 degree line in the top panel of Figure 4. Nordic countries dominate the list, occupying 4 of the top 6 positions. Since 1950, Sweden has had on average $0.1 \%$ of world population and $0.8 \%$ of world GDP, but has held $4.3 \%$ of senior positions in the Secretariat, including a Secretary-General from 1953-61. ${ }^{15}$ Western nations are also overrepresented, with the United States, Canada, and Great Britain all overrepresented by a factor of 2 or greater. Large, poor nations are significantly underrepresented; India, China, and Indonesia each have a world population share four or more times greater than their Secretariat position share.

[Table 2 about here.]

The high ranks of the Nordic countries are worth examining further. First, we note that the top six countries by representation are all small democracies. This is consistent with literature on small, open economies which finds that they take on additional insurance against negative shocks given their dependence on outside factors. These countries tend to have democratic corporatist relationships between business and labor (Katzenstein, 1985), larger governments (Rodrik, 2014), and strategic investments in security-focused international organizations (Mosser, 2000). That small, open economies would seek a greater role at the United Nations should is thus not surprising: investing in international institutions may be their best route to global influence.

Second, there may be a global perception that Nordic bureaucrats can be trusted to behave honestly and fairly. ${ }^{16}$ The high incidence of Nordic countries thus may not be the result of an exertion of power on their part, but a consequence of their fairness and reliability.

\footnotetext{
${ }^{15}$ These measures are not weighted by the expert measures of position importance, so we treat the SG equally to all other senior positions. Using the importance-weighted measures does not substantively change the list.

${ }^{16}$ Indeed, this has been a common reaction to presentations of this paper. It is also consistent with international surveys. Four of the top five countries by secretariat representation are among the 10 least corrupt according to Transparency International (2006). Bureaucrats from these countries appear wellbehaved as well, at least by the Fisman and Miguel (2007) measure: 9 of the top 10 countries by secretariat representation are among the 20 countries with the fewest parking tickets per diplomat.
} 
Nevertheless, finding themselves well represented in these senior positions gives the Nordic countries an opportunity to exercise power over international institutions; they may find it to their benefit to continue to cultivate a reputation for impartiality. After all, the ability to shape the preferences of other nations is one of the faces of power (Barnett and Duvall, 2005; Lukes, 1974); the other nations may not even realize the power they have bestowed on the Nordics.

\subsection{Evaluating the Staffing Mandate}

Table 3 presents estimates from a time series regression of annual Secretariat representation on population, human capital, freedom from corruption, and assessment of dues to the United Nations as described by Equation 1. An observation is a country-year, and standard errors are clustered at the country level. Columns 1 through 4 add independent variables sequentially. Column 5 repeats the estimation with all variables included, but rather than a count of senior positions, the outcome variable weights each position by the importance of that position, as judged by a third party expert. This last measure is rescaled so the total number of positions remains unity.

[Table 3 about here.]

The first row further weakens perceptions of the United Nations as a global democracy. The coefficient on population is insignificant across all four columns. Human capital enters positively with statistical significance. A 1 percentage point increase in a nation's share of the global stock of people with tertiary education is associated with a 0.2 to 0.4 percentage point increase in representation in the Secretariat. ${ }^{17}$ The freedom from corruption indicator

\footnotetext{
${ }^{17}$ One might be worried that our proxy of candidate qualification with tertiary education does not adequately take into account quality differences in education across countries. (We thank Michael Clemens for this suggestion.) The best measure of quality differentials is the OECDâs Program for International Student Assessment (PISA) testing of 15-year olds, first performed in 2000 in 32 countries; the 2012 tests included 65 countries. While the results cannot be applied to much of our sample given the short history of testing and narrowness of the sample, it is not obvious anecdotally that we have a large omission. Some of the best testing countries in 2012 like Singapore, Japan, and Vietnam are noticeably absent from the
} 
is also positive and significant in all specifications: countries with low corruption and good governance are better represented in the Secretariat. Assessment of dues also enters positively and significantly. Column 5 indicates that these results are robust to using importance weighted measures of Secretariat representation.

The results lend weight to the importance of the staffing mandate of the United Nations, suggesting that the supply of individuals of high competence and integrity plays a key role in the composition of the U.N. Secretariat, as does the assessment of dues.

The analysis thus far uses both cross-sectional and time series variation in representation. Table 4 presents estimates from a model with country fixed effects, and thus controls for any unobserved country-level variables (but also eliminates the interesting variation between countries). The results on population, assessment of dues and human capital are sustained; the effect of corruption is not visible in the time series alone, likely because it is available for only a third of the years and does not change significantly over time.

[Table 4 about here.]

We now examine the role of factors beyond the official staffing mandate of the United Nations.

\subsection{Factors Beyond the Staffing Mandate}

Table 5 shows the relationship between Secretariat representation and per capita wealth, military spending, investment in diplomacy, and democracy, controlling for the variables used in the staffing mandate regressions above. Human capital, military expenditure, GDP and assessment of dues are all highly colinear, which makes it difficult to separate their individual effects. ${ }^{18}$ Columns 1 through 3 show that these variables are positive, significant

top ranks in U.N. Secretariat. Conversely, among the ten most over-represented countries in the Secretariat (Table 2) only third-ranked Finland is a top-ten education quality performer in the much smaller sample of PISA-scoring countries.

${ }^{18}$ The correlation coefficients are $\rho_{G D P, \text { dues }}=0.98 ; \rho_{\text {dues, tertiaryed }}=0.92 ; \rho_{\text {dues, } \text { militaryshare }}=$ $0.89 ; \rho_{\text {militaryshare,tertiaryed }}=0.84$. Note that the per capita measures are less highly correlated, but as 
and very similar in magnitude when included separately.

Diplomacy enters with positive and highly significant point estimates, suggesting that investment in soft power is a key factor in determining representation in the U.N. Secretariat. A 1 percentage point increase in a country's share of the world's embassies is associated with a 0.5 to 0.7 percentage point increase in Secretariat representation.

Democracy and wealth are also positively correlated with representation, but not significant in all specifications. ${ }^{19}$

[Table 5 about here.]

When assessment, human capital stock and military spending are included together (column 4), the education variable dominates, but we are reluctant to infer too much from this since it is based on a small amount of variation between these three measures. ${ }^{20}$ When fixed effects are included (Appendix Table A2), results are upheld for all variables except diplomacy, which does not change significantly over time. ${ }^{21}$

Table 6 shows how the correlates of U.N. Secretariat representation have changed over time, by estimating the main specification separately for each decade. Estimates are noisier due to the smaller sample sizes, but we find that diplomacy has a consistent and large effect over time. Population and freedom from corruption are insignificant in all decades. With the same qualification about multicollinearity as above, among assessment (GDP), human capital, and military spending, we find that human capital is more important in the 1970s and 1980s while assessment plays a larger role in the 1990s and 2000s. Meanwhile, democracy wanes in importance while wealth rises in importance. Taken together, these

described above the gross measures are more appropriate to our specification.

${ }^{19}$ As above, results are robust to the use of the weighted representation measure, as well as to the exclusion of the United States. These tables are available upon request from the authors.

${ }^{20}$ We chose to use the military expenditure measure rather than the widely used Composite Index of National Capability (CINC) because the latter already includes several variables that are identical or very highly correlated with population and GDP, which we wish to control for separately. However, our results are robust to the use of CINC in place of military expenditure share and available upon request.

${ }^{21}$ Country fixed effects explain $89 \%$ of the variation in diplomatic contacts. 
results are consistent with the notion that the staff were initially drawn more from educated democracies, but as global education and governance levels have risen over time, economic strength has played a larger role.

[Table 6 about here.]

\section{Extension: Power, Alliances, and the Pax Ameri-} cana

In the struggle to control international institutions, as in military matters, alliances are important. Consider the campaign to prevent global warming. Countries form coalitions to advance their shared interests. This suggests we may have a problem of measurement error if we restrict our attention to a country's own representation in an international organization and ignore the combined power of its alliance. Palau, for instance, might be equally satisfied between holding a Secretariat position itself or having Maldives hold a position, since both low-lying island nations share the same goal of preventing climate change. The United States might be content to have Canadians and New Zealanders staff the peacekeeping department, since their outlook, strategy, and judgment would likely be similar to their own.

We can extend our analysis by taking alliances, or shared preferences, into account. We use the term alliance loosely, recognizing that our statistical measures can only serve as im-

perfect proxies for true underlying alliances or coalitions. In this section we will augment the basic count of Secretariat positions with an alliance-weighted measure. As a demonstration of the potential to use Secretariat staffing as a measure of power, we consider the case of the United States.

One of the most public debates in the field of power and international relations is whether the United States' power is in decline. As Joseph Nye wrote in, "The Decline and Fall of America's Decline and Fall" (2011a), America's decline has been frequently anticipated: 
first the Soviets in the 1950s and 1960s, then the Japanese in the 1980s, and now the Chinese have all been predicted to "get the better of America." Taking the long view, Paul Kennedy had predicted decline (1989) but even by 2012 many prominent writers were unconvinced (Kagan, 2012; Lieber, 2012). A parallel, and sometimes overlapping debate has been occurring on whether we are in an era of "American Empire" (Nexon and Wright, 2007). The breadth of opinions leaves open the question of whether America's power is in decline, fluctuating, or indeed in ascent. Our measure of Secretariat representation offers an objective and consistent methodology for contributing to this debate.

As Figure 2 depicts, the United States was significantly overrepresented in the early years of the United Nations' existence. Its share of positions declined steadily until around 1980, and has since remained relatively constant and modest. At first glance this appears to be a fall in institutional power from 1950 through 1980, as other nations, notably Germany and Japan in the figure, increased in prominence. This is consistent with the Kennedy view.

However, this raw scoring ignores the fact that the United States structured the international system after W.W.II to help enforce the so-called Pax Americana. With the United Nations and the Bretton Woods organizations, the United States, wrote John Ikenberry, "spun a web of institutions that connected other states to an emerging American-dominated economic and security order" (Ikenberry, 2001). The plan may never have been to dominate the individual institutions once they matured but rather to share them with other nations who subscribed to the American worldview. We must thus consider the possibility that U.S. allies might have held, or gained ground, in the Secretariat even as the United States' individual representation has fallen, as suggested by the steady share of positions held by Western countries, visible in Figure 3. If these countries' international bureaucrats share American objectives and preferences, then it may be that the interests of the United States are no less represented in the international system than they were in 1960 when U.S. staff representation was at its peak. 
While this view seems plausible for the Cold War years, the notion of a "Western Europe and offshoot" alliance in recent international affairs is less obvious. The United States often has significant disagreement with European countries in matters of international organization, with Americans becoming increasingly unilateralist and Europeans multilateralists (Rubenfeld, 2004). Our data can shed light on these issues.

\section{$5.1 \quad$ Alliance-Weighted Representation}

Taking alliances into account allows us to more comprehensively answer the question of whether the United States is in decline, by examining whether closely allied nations have acquired the positions that America has lost.

Measuring alliances as they relate to the multifaceted job of running the United Nations is not easy. Restricting our attention to data that could be analyzed in panel form, we could use several possible proxies - any of which could be used in the methodology that we describe below. We elect to proxy preference similarity by focusing on U.N. voting records, as we think it comes the closest to measuring the relevant dimension of alliances for the management of the Secretariat. We repeated the exercise below using common membership in intergovernmental organizations (Pevehouse et al., 2004) as another measure of alliance, with broadly similar results. ${ }^{22}$ Other possible variables, such as formal military alliances or international public opinion data could also be used.

We use U.N. General Assembly voting data (Gartzke, 2006) to generate a unique, dynamic, and synthetic alliance for any country. The assumption behind our formulation is that bureaucrats from two countries with identical preferences over General Assembly resolutions will behave in the same manner if given senior positions in the Secretariat. Alternately, one country has just as much alliance-weighted representation when its close ally holds a position as when the country itself does. Pairs of countries with weaker correlations in voting

\footnotetext{
${ }^{22}$ Results available from the authors upon request.
} 
behavior receive correspondingly less benefit from each others' positions.

We model country j's alliance-weighted influence as:

$$
\operatorname{INFLUENCE}_{j, t}=\sum_{i \in I} \operatorname{POSITIONS}_{i, t} * A F F I N I T Y_{i, j, t}
$$

where POSITIONS $S_{i, t}$ is the share of positions held by country $i$ at time $t$ and AFFINITY $Y_{i, j, t}$ is a measure of the similarity of voting in the General Assembly between countries $i$ and $j$ in year $t$, with $A F F I N I T Y_{i, i, t}=1$. Specifically, for any given year, $A F F I N I T Y_{i, j}=$ $1-2 * \frac{d}{d^{\text {max }}}$, where $d$ is the number of times that $i$ votes against $j$, and $d^{\text {max }}$ is the number of General Assembly votes. ${ }^{23}$ In words, a country $j$ 's alliance-weighted influence is a weighted average of the influence of all countries in the world, where the weighting is determined by how much country $j$ votes like the other countries.

This alliance-weighted measure is slightly unrealistic as an indicator of national power in that it describes a small country and a large country with very similar voting records (Iceland and Sweden, for example) as being equally powerful. Surely, Sweden exerts more control over the United Nations than Iceland. Yet from the perspective of an individual Swede or Icelander, there is no difference in terms of whether one country or the other is exercising agency at the U.N.. Moreover, to capture the difference between Iceland and Sweden here, it would suffice to look at each country's raw representation in tandem with their alliance-weighted representation.

The other concern with our approach is that General Assembly voting might not be an adequate measure of the difference between two countries' preferences. There are some documented weaknesses in such use of the data but it is nonetheless the methodology of choice in dozens of papers in political science and economics (Voeten, 2013). For those scholars who would prefer a different dyadic measure of preference similarity, that variable

\footnotetext{
${ }^{23}$ AFFINITY and INFLUENCE are thus both bounded between -1 and 1 .
} 
could be substituted for AFFINITY in equation 2.

Defining the United States as "country $j$," the solid lines in Figure 5 show U.S. influence in the Secretariat over time (black), along with the unadjusted U.S. Secretariat representation measure from (gray) Figure 2. The measures track each other until the mid-1960s. From 1965 to 1980, the number of positions held by Americans declines, but America's allianceweighted representation remains constant, as those positions are filled by American allies.

[Figure 5 about here.]

Around 1980, U.S. alliance-weighted influence falls in the Secretariat and drops below zero, indicating that the average senior official in the Secretariat is from a nation that is an opponent of the U.S. rather than an ally. From 1981 to 2007, Secretariat affinity with the U.S. remains largely negative, with a slight upturn during the Clinton administration and a monotonic fall during the subsequent Bush years.

These changes in alliance-weighted representation could be driven by either a change in composition of the Secretariat or a change in General Assembly voting behavior of countries. In other words, a country loses influence when (i) it or its allies lose Secretariat positions; or (ii) countries that already have positions become more opposed to the country in question. We can test between these two alternatives by examining a hypothetical scenario where alliances have not changed since the 1950s. This scenario is represented by the dashed line in Figure 5. When we hold alliances constant, the U.S. decline is almost completely eliminated, indicating that all of the lost American positions were taken by its 1950s allies, but that these allies no longer share ideology with the United States.

This exercise suggests that U.S. influence in the United Nations has significantly waned over time, such that the Secretariat is no longer a projection of U.S. power. The mechanisms behind this finding are nevertheless consistent with the idea that the characteristics of international organizations persist beyond the conditions of their origination (Keohane, 1984; Ikenberry, 2001). But this is not to say that the balance of power in those organiza- 
tions is static; the Secretariat is as pro-Western as ever, but the main beneficiaries are the former allies of the United States rather than America itself. In assisting in the creation of an organization that would be dominated by the West rather than dominated America (Ikenberry, 2001), the United States in the 1940s may have constrained its own future administrations to be more Wilsonian than they would otherwise be.

\subsection{Measuring Institutional Bias}

We have shown a secular decline in U.S. power as expressed by the staffing of the Secretariat from 1950 to the present. It remains possible that the Secretariat has a pro-U.S. bias relative to the world, even while the influence measure of the United States is negative. In other words, a U.N. Secretariat that is opposed to the United States might be even more opposed to the United States if it represented all countries equally.

We extend our methodology to measure the international bias of an institution, defined as the difference between the institution-country affinity measure and a population-weighted measure of the world's affinity for the country. ${ }^{24}$

First, we create a variable analogous to INFLUENCE above but instead of weighting with Secretariat positions, we weight with world population. This gives us a populationweighted measure of the affinity of the world for a given country:

$$
O P I N I O N_{U S A, t}=\sum_{i \in I} P O P U L A T I O N_{i, t} * A F F I N I T Y_{i, U S A, t},
$$

where POPULATION $N_{i, t}$ is country $i$ 's share of world population at time $t$. This measure describes what the variable INFLUENCE would be if the nationality distribution in the

\footnotetext{
${ }^{24}$ The use of population weights implies that our reference point is a situation where all people in the world are represented equally. Our premise is that any departure from such a point is a reflection of national influence over the Secretariat, which is exactly what we want to measure. If we were to use a residual from one of the regressions in the previous section, we would be omitting the effect on power of any of the regression variables in the analysis.
} 
Secretariat matched that of the world. We then define the bias of an institution - in our case the U.N. Secretariat - toward the views of a country as the difference between the country's affinity with the institution and the country's affinity with the world:

$$
B I A S_{U S A, t}=I N F L U E N C E_{U S A, t}-O P I N I O N_{U S A, t} .
$$

We plot BIAS for the United States over time in Figure 6. The figure shows that relative to the world as a whole, the U.N. Secretariat has been consistently biased toward the United States. If the staffing of the Secretariat were proportional to national populations, the United States would have even less influence over the institution. In other words, despite increased U.S. isolation (as expressed by voting in the General Assembly), the United States benefits from a relatively friendly Secretariat. The U.S. has lost influence in the U.N. Secretariat since 1980, but it has fallen even further in the eyes of the world. The Pax Americana seems to benefit the United States after all.

[Figure 6 about here.]

This methodology can be used to examine the bias of any international organization, given data on the nationalities of key officials. As an example, we analyze the bureaucratic leadership of the United Nations Educational, Scientific, and Cultural Organization (UNESCO) during the 1970s and early 1980s. This U.N. specialized agency was only the second U.N. agency from which the United States withdrew, in $1984^{25}$ (Joyner and Lawson, 1986). UNESCO's General Conference regularly adopted anti-Israel resolutions, sponsored disarmament activities that the Americans thought were biased in favor of Soviet positions, and promoted restrictions on the freedom of the press through the controversial New World Information and Communication Order (NWICO) (Jacobson, 1984; Puchala, 1990). UNESCO's Secretariat played a decisive role in the organization's stance and direction (Joyner and Law-

\footnotetext{
${ }^{25}$ The U.S. withdrew from the International Labor Organization from 1978-80.
} 
son, 1986). In Figure 7 we compute UNESCO's pro-U.S. bias and compare it with the U.N. Secretariat through 1988, the last year for which we have leadership data on UNESCO. As can be seen in the figure, UNESCO is notably less pro-American than the Secretariat. This imbalance would be significantly greater if not for a single directorship held by the United States for most of this period, a position which likely played a role in scuttling the NWICO effort.

[Figure 7 about here.]

\section{Conclusion}

In 1946, Norwegian Trygve Lie was made the first Secretary General of the United Nations, in part because of the strong Soviet opinion that the position should go to someone who was neither British, French, nor American (Thant and Scott, 2007). The Nordic countries have since continued to dominate the senior ranks of the United Nations, perhaps in part because their citizens are perceived as neutral and trustworthy. Whatever the reason, it is perhaps no accident that the bureaucratic arms of the United Nations tend toward an ideology that is not dissilimar to that of the Nordic nations. To the extent that international institutions constrain the actions of states, the Nordic countries are in a far more influential international position than their economic or military strength would suggest.

We have argued that countries with greater ability to influence international organizations will be more successful in placing their nationals into senior positions, and that this is an increasingly important aspect of state power. Since these positions are scarce and central to the operation of the United Nations, the resulting allocation of senior positions gives us information on countries' ability to compete for influence in the international system. In spite of the modesty of its setting, this measure of power has some advantages over traditional capability-based measures. 
We find that democracies, countries that invest in bilateral diplomacy, and economically/militarily powerful countries are the most effective at placing staff in the Secretariateven after controlling for monetary contributions to the U.N. and the staffing mandate of competence and integrity. This suggests that exercising influence via a multilateral institution is a complement to exercising it through traditional bilateral diplomacy. Examining our measure over time, we find that Western Europe and its offshoots have retained control over a disproportionate share of positions in the Secretariat, even while their share of global GDP and population has fallen.

Going further, we put forward a measure of representation that takes shared preferences between countries into account. We examine the alliance-weighted representation of the United States and find that American influence has been in decline since the formation of the United Nations, especially since 1980, and that the growing ideological distance between the United States and its 1950 allies plays an important role in this decline. However, the Secretariat remains weakly biased toward the interests of the United States, when compared with the interests of the world as a whole.

This paper is not a conclusive operationalization of power, or a comprehensive answer to the question of who runs the world. Rather, it attempts to plumb the rich information hidden in plain sight, which is the national composition of the senior staff of the world's most global institution. This information offers a quantifiable approach to help understand how nations interact in a globalized context. 
Table 1

Summary statistics

\begin{tabular}{lccccc}
\hline \hline Variable & Mean & Standard Deviation & Min & Max & N \\
\hline Number of senior Secretariat positions & 0.4 & 1.0 & 0.0 & 11.0 & 8933 \\
Share of senior Secretariat positions & 0.01 & 0.02 & 0.00 & 0.28 & 8933 \\
GDP (million USD) & 128,862 & 640,398 & 30 & $13,983,709$ & 6120 \\
GDP share & 0.01 & 0.03 & 0.00 & 0.45 & 6120 \\
Population (millions) & 29.9 & 103.5 & 0.1 & $1,311.0$ & 8519 \\
Population share & 0.01 & 0.02 & 0.00 & 0.23 & 8519 \\
Population with higher ed (million) & 0.72 & 3.11 & 0.00 & 56.16 & 7338 \\
Human capital share & 0.01 & 0.03 & 0.00 & 0.43 & 7338 \\
Inverse corruption index & -0.1 & 1.0 & -2.2 & 2.6 & 1198 \\
Inverse corruption (rescaled) & 0.0 & 1.0 & -2.0 & 2.7 & 1198 \\
UN Fee Assessment & 0.01 & 0.03 & 0.00 & 0.33 & 6120 \\
Military expenditure (thousand USD) & 4,510 & 24,619 & 0 & 552,568 & 6732 \\
Military spending share & 0.01 & 0.04 & 0.00 & 0.52 & 6732 \\
Democracy (Polity) & 0.3 & 7.5 & -10.0 & 10.0 & 6857 \\
Democracy (Polity, rescaled) & -0.0 & 1.0 & -2.2 & 1.7 & 6857 \\
GDP Per Capita & 3,789 & 7.649 & 38 & 82,020 & 6120 \\
GDP Per Capita (rescaled) & -0.0 & 1.0 & -0.9 & 6.0 & 6120 \\
Diplomatic contacts & 36 & 29 & 0 & 156 & 6080 \\
Diplomatic contacts (share) & 0.01 & 0.01 & 0.00 & 0.04 & 6080 \\
\hline
\end{tabular}




\section{Table 2}

Secretariat representation, all years, excess over population

\begin{tabular}{|c|c|c|c|c|}
\hline Rank & Country & Share of positions & Share of world population & Excess Representation \\
\hline 1 & Sweden & 0.0428 & 0.0015 & 21.67 \\
\hline 2 & Norway & 0.0180 & 0.0007 & 18.69 \\
\hline 3 & Finland & 0.0206 & 0.0009 & 17.90 \\
\hline 4 & New Zealand & 0.0114 & 0.0006 & 15.97 \\
\hline 5 & Ireland & 0.0109 & 0.0006 & 13.67 \\
\hline 6 & Denmark & 0.0150 & 0.0009 & 12.43 \\
\hline 7 & Panama & 0.0050 & 0.0005 & 11.68 \\
\hline 8 & Jamaica & 0.0047 & 0.0004 & 9.72 \\
\hline 9 & Switzerland & 0.0118 & 0.0012 & 7.93 \\
\hline 10 & Uruguay & 0.0053 & 0.0005 & 7.68 \\
\hline 11 & Sierra Leone & 0.0056 & 0.0007 & 7.44 \\
\hline 12 & Jordan & 0.0037 & 0.0008 & 7.27 \\
\hline 13 & Canada & 0.0382 & 0.0051 & 6.93 \\
\hline 14 & Ghana & 0.0178 & 0.0032 & 6.75 \\
\hline 15 & Botswana & 0.0015 & 0.0003 & 6.63 \\
\hline 16 & Greece & 0.0149 & 0.0018 & 6.62 \\
\hline 17 & Chile & 0.0161 & 0.0025 & 6.38 \\
\hline 18 & Austria & 0.0117 & 0.0013 & 6.38 \\
\hline 19 & Tunisia & 0.0083 & 0.0016 & 5.70 \\
\hline 20 & Senegal & 0.0068 & 0.0016 & 5.27 \\
\hline 22 & Australia & 0.0150 & 0.0031 & 4.55 \\
\hline 24 & United Kingdom & 0.0581 & 0.0097 & 4.28 \\
\hline 29 & Argentina & 0.0224 & 0.0061 & 3.49 \\
\hline 36 & France & 0.0343 & 0.0097 & 2.72 \\
\hline 38 & United States & 0.1292 & 0.0464 & 2.46 \\
\hline 44 & Italy & 0.0264 & 0.0094 & 2.00 \\
\hline 46 & Egypt & 0.0173 & 0.0115 & 1.70 \\
\hline 51 & Colombia & 0.0082 & 0.0065 & 1.39 \\
\hline 52 & Pakistan & 0.0259 & 0.0227 & 1.37 \\
\hline 53 & Poland & 0.0100 & 0.0063 & 1.23 \\
\hline 56 & Myanmar & 0.0085 & 0.0077 & 1.14 \\
\hline 62 & South Africa & 0.0060 & 0.0072 & 0.95 \\
\hline 63 & Germany & 0.0158 & 0.0135 & 0.84 \\
\hline 64 & Iran & 0.0072 & 0.0105 & 0.82 \\
\hline 66 & Philippines & 0.0085 & 0.0128 & 0.79 \\
\hline 67 & Japan & 0.0206 & 0.0208 & 0.78 \\
\hline 68 & Nigeria & 0.0131 & 0.0205 & 0.78 \\
\hline 69 & Russian Federation & 0.0237 & 0.0240 & 0.74 \\
\hline 75 & Sudan & 0.0030 & 0.0057 & 0.66 \\
\hline 76 & Tanzania & 0.0029 & 0.0056 & 0.66 \\
\hline 78 & Mexico & 0.0091 & 0.0161 & 0.63 \\
\hline 81 & Spain & 0.0048 & 0.0066 & 0.57 \\
\hline 83 & Brazil & 0.0131 & 0.0286 & 0.49 \\
\hline 85 & Turkey & 0.0045 & 0.0109 & 0.44 \\
\hline 86 & Korea, Rep. & 0.0034 & 0.0077 & 0.42 \\
\hline 89 & India & 0.0447 & 0.1670 & 0.29 \\
\hline 90 & Indonesia & 0.0055 & 0.0337 & 0.17 \\
\hline 91 & Bangladesh & 0.0032 & 0.0231 & 0.16 \\
\hline 92 & Thailand & 0.0008 & 0.0102 & 0.08 \\
\hline 94 & Ethiopia & 0.0005 & 0.0108 & 0.05 \\
\hline 95 & China & 0.0086 & 0.2075 & 0.04 \\
\hline 96 & Congo, Dem. Rep. & 0.0000 & 0.0084 & 0.00 \\
\hline 96 & Romania & 0.0000 & 0.0037 & 0.00 \\
\hline 96 & Ukraine & 0.0000 & 0.0081 & 0.00 \\
\hline 96 & Vietnam & 0.0000 & 0.0128 & 0.00 \\
\hline
\end{tabular}




\section{Table 3}

\section{Correlates of U.N. Secretariat representation}

\begin{tabular}{lccccc}
\hline \hline & $(1)$ & $(2)$ & $(3)$ & $(4)$ & $(5)$ \\
\hline Population share & 0.211 & -0.005 & 0.011 & 0.018 & 0.008 \\
& $(0.141)$ & $(0.065)$ & $(0.069)$ & $(0.077)$ & $(0.075)$ \\
Human capital share & & 0.398 & 0.370 & 0.168 & 0.229 \\
& & $(0.014)^{* * *}$ & $(0.014)^{* * *}$ & $(0.110)$ & $(0.089)^{* *}$ \\
Inverse corruption (rescaled) & & & 0.004 & 0.003 & 0.003 \\
& & & $(0.001)^{* * *}$ & $(0.001)^{* * *}$ & $(0.001)^{* * *}$ \\
UN Fee Assessment & & & 0.259 & 0.217 \\
& & & & $(0.142)^{*}$ & $(0.115)^{*}$ \\
Constant & 0.005 & 0.004 & 0.004 & 0.004 & 0.004 \\
& $(0.001)^{* * *}$ & $(0.001)^{* * *}$ & $(0.001)^{* * *}$ & $(0.001)^{* * *}$ & $(0.001)^{* * *}$ \\
\hline $\mathrm{N}$ & 8519 & 7306 & 7170 & 5464 & 5464 \\
$\mathrm{r} 2$ & 0.08 & 0.47 & 0.52 & 0.55 & 0.57 \\
\hline
\end{tabular}

${ }^{*} p<0.10,{ }^{* *} p<0.05,{ }^{* * *} p<0.01$

The table shows coefficients from estimation of Equation 1, with the share of positions in the United Nations Secretariat as the dependent variable. Each observation is a country-year. Columns 1 through 4 add covariates sequentially. The dependent variable in column 5 is the share of weighted secretariat representation, with weights equal to expert rankings of the important of each position. Population, human capital and assessment of dues are represented as world shares. The freedom from corruption index is rescaled to have a mean of 0 and standard deviation of 1 in each year. Standard errors are clustered by country. 


\section{Table 4}

\section{Correlates of U.N. Secretariat representation (Country Fixed Effects)}

\begin{tabular}{lccccc}
\hline \hline & $(1)$ & $(2)$ & $(3)$ & $(4)$ & $(5)$ \\
\hline Population share & 0.835 & -0.043 & -0.021 & 0.524 & 0.402 \\
& $(0.719)$ & $(0.555)$ & $(0.564)$ & $(0.581)$ & $(0.534)$ \\
Human capital share & & 0.594 & 0.621 & 0.405 & 0.474 \\
& & $(0.137)^{* * *}$ & $(0.140)^{* * *}$ & $(0.118)^{* * *}$ & $(0.115)^{* * *}$ \\
Inverse corruption (rescaled) & & & 0.000 & -0.000 & 0.000 \\
& & & $(0.001)$ & $(0.001)$ & $(0.001)$ \\
UN Fee Assessment & & & 0.509 & 0.473 \\
& & & & $(0.127)^{* * *}$ & $(0.109)^{* * *}$ \\
\hline $\mathrm{N}$ & 8519 & 7306 & 7170 & 5464 & 5464 \\
$\mathrm{r} 2$ & 0.65 & 0.69 & 0.69 & 0.72 & 0.73 \\
\hline$* 2<0.107^{* *} p<0.05^{* * *} p<0.01$ & & & &
\end{tabular}

${ }^{*} p<0.10,{ }^{* *} p<0.05,{ }^{* * *} p<0.01$

The table shows coefficients from estimation of Equation 1, with the share of positions in the United Nations Secretariat as the dependent variable, and country fixed effects. Each observation is a countryyear. Columns 1 through 4 add covariates sequentially. The dependent variable in column 5 is the share of weighted secretariat representation, with weights equal to expert rankings of the important of each position. Population, human capital and assessment of dues are represented as world shares. The freedom from corruption index is rescaled to have a mean of 0 and standard deviation of 1 in each year. Standard errors are clustered by country-decade pairs. 


\section{Table 5}

\section{Additional Correlates of U.N. Secretariat Representation}

\begin{tabular}{lcccc}
\hline \hline & $(1)$ & $(2)$ & $(3)$ & $(4)$ \\
\hline Population share & -0.009 & 0.039 & 0.029 & -0.007 \\
Human capital share & $(0.054)$ & $(0.066)$ & $(0.075)$ & $(0.056)$ \\
& 0.259 & & & 0.239 \\
UN Fee Assessment & $(0.017)^{* * *}$ & & & $(0.073)^{* * *}$ \\
& & 0.289 & & 0.011 \\
Military spending share & & $(0.058)^{* * *}$ & & $(0.088)$ \\
& & & 0.217 & 0.012 \\
Inverse corruption (rescaled) & -0.000 & -0.000 & -0.001 & -0.000 \\
& $(0.001)$ & $(0.001)$ & $(0.001)$ & $(0.001)$ \\
GDP Per Capita (rescaled) & 0.002 & 0.002 & 0.002 & 0.002 \\
& $(0.001)^{* *}$ & $(0.001)$ & $(0.001)^{* *}$ & $(0.001)^{*}$ \\
Diplomatic contacts (share) & 0.676 & 0.529 & 0.761 & 0.667 \\
& $(0.163)^{* * *}$ & $(0.157)^{* * *}$ & $(0.169)^{* * *}$ & $(0.159)^{* * *}$ \\
Democracy (Polity, rescaled) & 0.001 & 0.001 & 0.002 & 0.001 \\
& $(0.001)$ & $(0.001)$ & $(0.001)^{* *}$ & $(0.001)$ \\
Constant & 0.001 & 0.001 & 0.001 & 0.001 \\
& $(0.001)$ & $(0.001)$ & $(0.001)$ & $(0.001)$ \\
\hline $\mathrm{N}$ & 4615 & 5023 & 4937 & 4552 \\
$\mathrm{r} 2$ & 0.54 & 0.51 & 0.51 & 0.53 \\
\hline${ }^{*} p<0.10{ }^{* *} p<0.05{ }^{* * *} p<0.01$ & & &
\end{tabular}

The table shows coefficients from estimation of Equation 1, with the share of positions in the United Nations Secretariat as the dependent variable. Each observation is a countryyear. Columns 1 through 3 separately include the highly colinear Assessment of Dues, Share of Tertiary Educated Population and Share of Military Spending. Column 4 adds a control for share of all UN secretariat staff (i.e. not only senior), a variable which we have for only 2008. Column 5 includes the three colinear controls together. Population, human capital, assessment of dues, diplomatic contacts and military spending are represented as world shares. The freedom from corruption index, Polity score and per capita wealth are rescaled to have a mean of 0 and standard deviation of 1 in each year. Standard errors are clustered by country. 


\section{Table 6}

\section{Coefficients on Secretariat Representation Over Time}

\begin{tabular}{lccccc}
\hline \hline & 1960 & 1970 & 1980 & 1990 & 2000 \\
\hline Population share & 1.255 & 0.303 & 0.540 & 0.464 & 0.356 \\
& $(0.411)^{* * *}$ & $(0.162)^{*}$ & $(0.146)^{* * *}$ & $(0.255)^{*}$ & $(0.287)$ \\
Population Share ${ }^{2}$ & -6.333 & -1.640 & -2.238 & -2.138 & -1.767 \\
& $(1.921)^{* * *}$ & $(0.744)^{* *}$ & $(0.653)^{* * *}$ & $(1.109)^{*}$ & $(1.360)$ \\
Human capital share & -0.330 & 0.400 & 0.131 & -0.068 & -0.083 \\
& $(0.258)$ & $(0.088)^{* * *}$ & $(0.121)$ & $(0.132)$ & $(0.139)$ \\
Inverse corruption (rescaled) & -0.001 & 0.001 & 0.000 & -0.000 & 0.002 \\
& $(0.001)$ & $(0.001)$ & $(0.001)$ & $(0.001)$ & $(0.001)^{*}$ \\
UN Fee Assessment & -0.039 & -0.385 & -0.057 & 0.164 & 0.249 \\
& $(0.219)$ & $(0.063)^{* * *}$ & $(0.087)$ & $(0.065)^{* *}$ & $(0.103)^{* *}$ \\
GDP Per Capita (rescaled) & 0.005 & 0.000 & 0.003 & 0.003 & 0.002 \\
& $(0.003)^{* *}$ & $(0.001)$ & $(0.002)$ & $(0.001)^{* *}$ & $(0.002)$ \\
Military spending share & 0.658 & 0.173 & 0.014 & 0.033 & 0.026 \\
& $(0.281)^{* *}$ & $(0.108)$ & $(0.072)$ & $(0.081)$ & $(0.045)$ \\
Diplomatic contacts (share) & 0.094 & 0.733 & 0.287 & 0.577 & 0.466 \\
& $(0.271)$ & $(0.219)^{* * *}$ & $(0.205)$ & $(0.219)^{* * *}$ & $(0.211)^{* *}$ \\
Democracy (Polity, rescaled) & 0.001 & 0.002 & 0.002 & 0.001 & -0.001 \\
& $(0.001)$ & $(0.001)^{* *}$ & $(0.001)^{* * *}$ & $(0.001)$ & $(0.001)$ \\
Constant & 0.002 & 0.001 & 0.003 & 0.000 & 0.001 \\
& $(0.002)$ & $(0.001)$ & $(0.002)^{*}$ & $(0.001)$ & $(0.001)$ \\
\hline N & 712 & 927 & 974 & 1117 & 822 \\
r2 & 0.73 & 0.61 & 0.49 & 0.51 & 0.58 \\
\hline$*<0.10{ }^{* *} p<0.05 *^{* *} p<0.019$ & & &
\end{tabular}

${ }^{*} p<0.10,{ }^{* *} p<0.05,{ }^{* * *} p<0.01$

The table shows coefficients from estimation of Equation 1, with the share of positions in the United Nations Secretariat as the dependent variable, and the sample split by decade. Each observation is a country-year. Population, human capital, assessment of dues, diplomatic contacts and military spending are represented as world shares. The freedom from corruption index, Polity score and per capita wealth are rescaled to have a mean of 0 and standard deviation of 1 in each year. Standard errors are clustered by country. 


\section{Figure 1}

\section{Number of positions listed and identified in U.N. Yearbook}

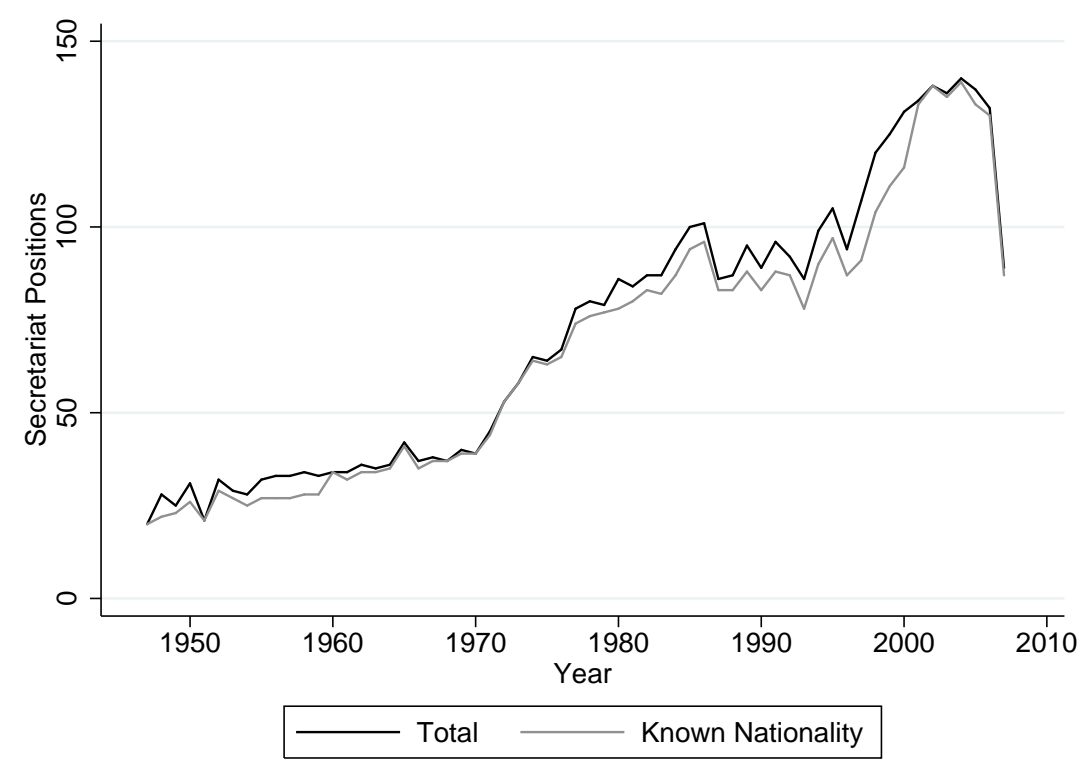

The figure shows the number of positions listed in the Appendix of the U.N. Yearbook, "Key Staff of the U.N. Secretariat," along with the number of those position-holders that were matched to nationalities. Our main measure of representation is the share of positions held by each nation in a given year. 


\section{Figure 2}

\section{Secretariat Representation of World Powers Over Time}

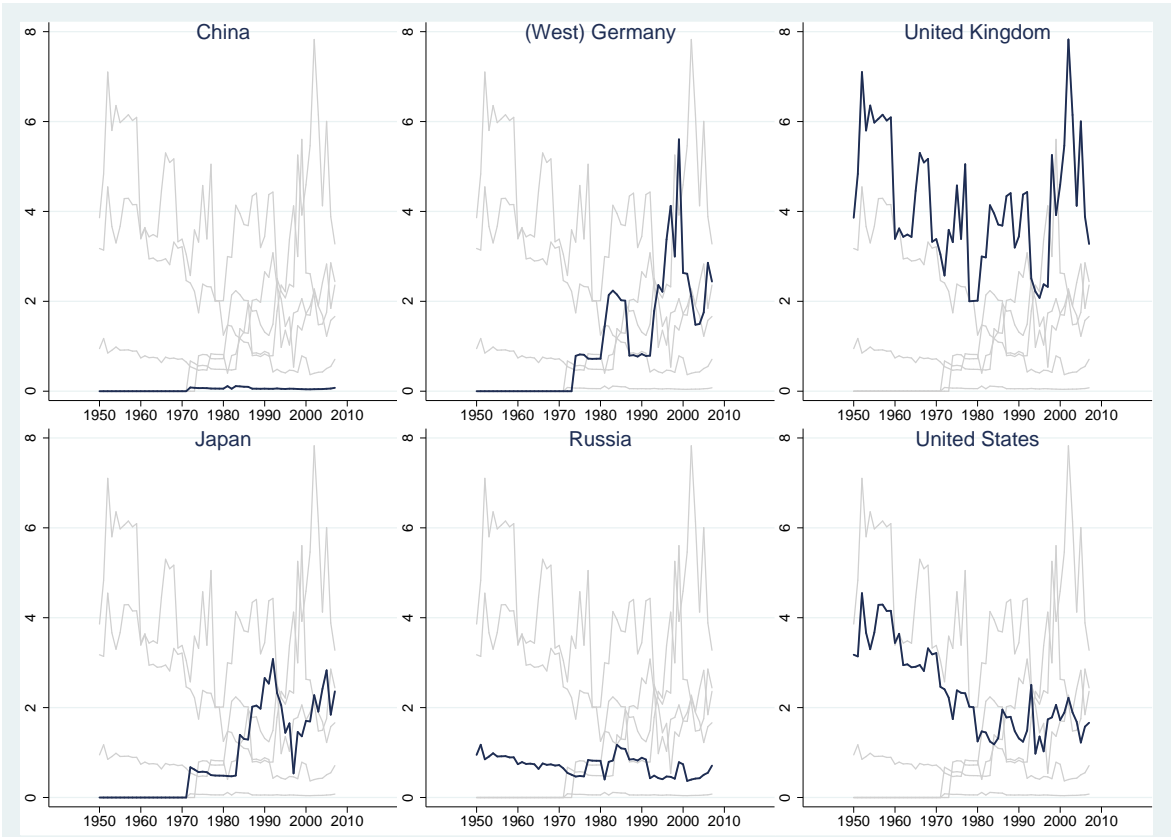

The figure shows annual excess representation in the United Nations Secretariat of selected world powers over time. The y axis is excess representation, defined as a country's share of senior Secretariat positions divided by a country's share of world population. 
Figure 3

Secretariat and Population Share of Western Europe and Offshoots

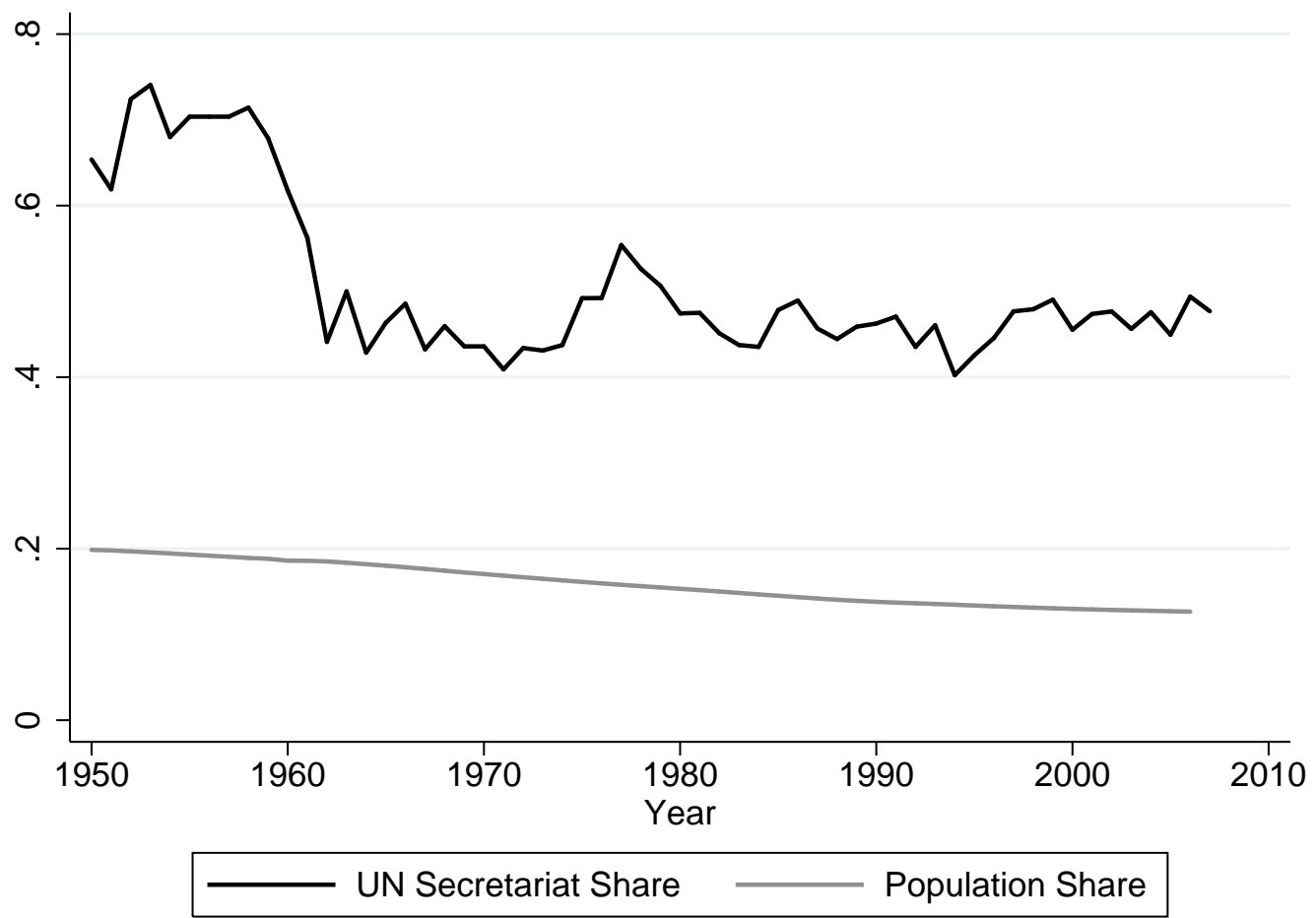

The figure shows, over time, the share of senior positions in the United Nations Secretariat held by Western Europe and its offshoots (United States, Canada, Australia, New Zealand), and the world population share of these same powers. 


\section{Figure 4}

\section{Secretariat representation vs. population and GDP}
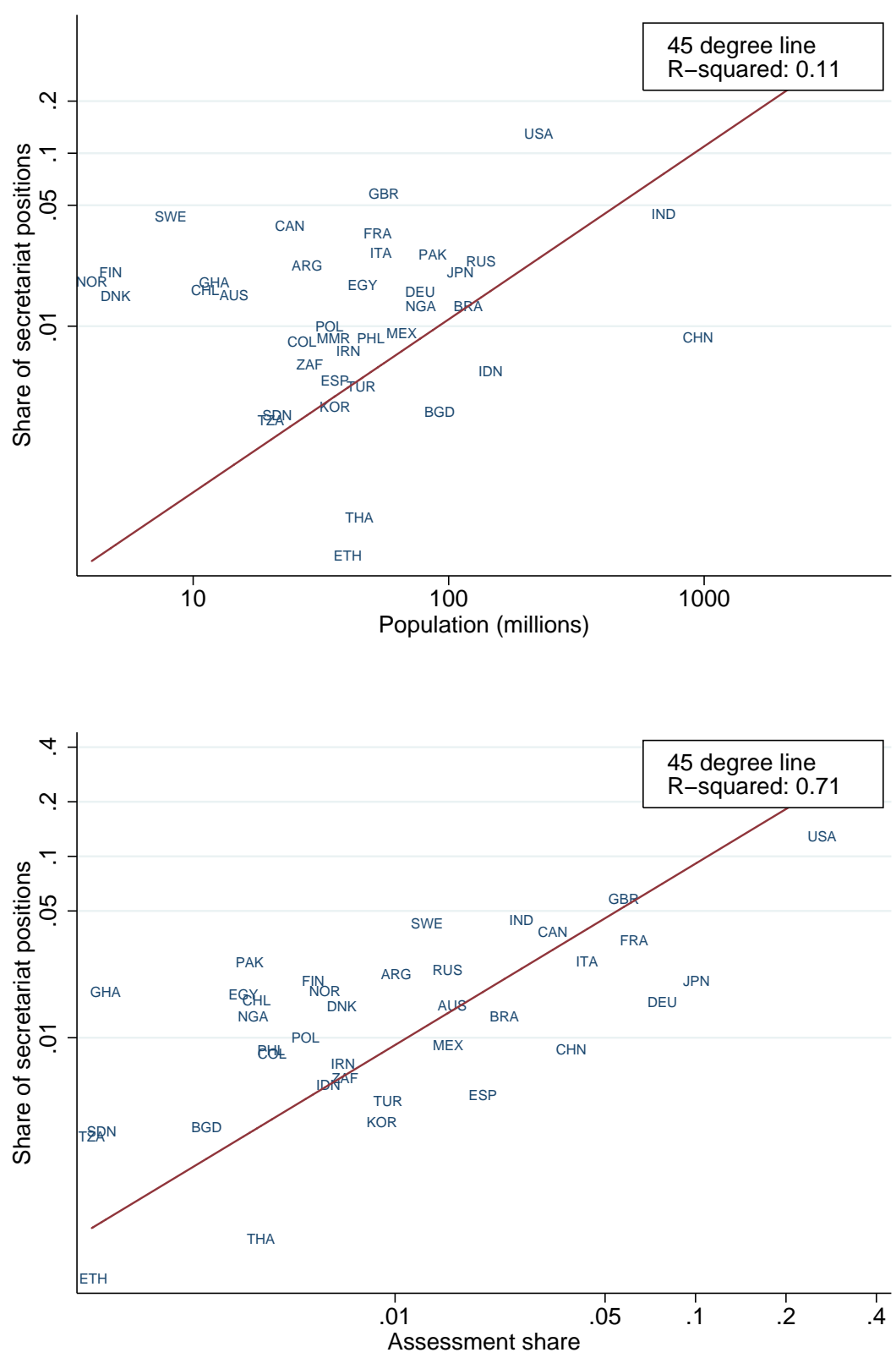

The top panel of the figure shows a scatter plot of the average share of secretariat positions held across all years against the average population of a country in all years. The solid line is not a best fit, but a 45 degree line. Countries above the line are overrepresented in the secretariat relative to their population, while countries below the solid line are underrepresented. The bottom panel of the figure shows the same plot, but with assessment of dues to the United Nations on the $\mathrm{X}$ axis. For readability, the graphs are presented on logarithmic scales, and the sample is limited to all countries with population greater than 20 million, as well as the 20 most countries with the most senior positions in the Secretariat. 


\section{Figure 5}

\section{Secretariat affinity for USA}

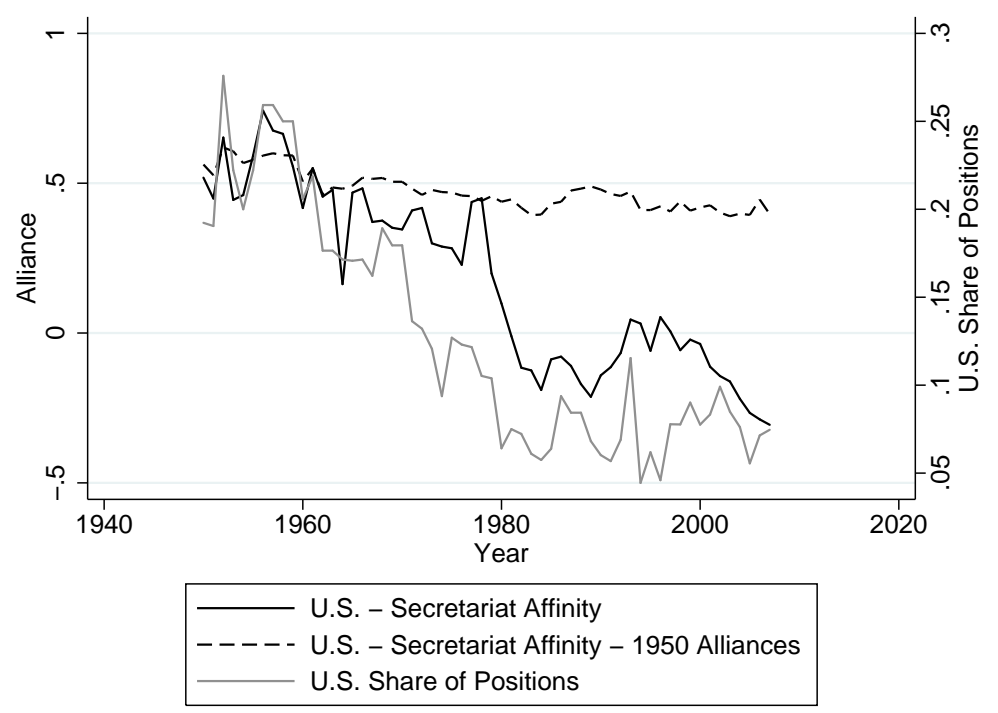

The figure shows how U.S. influence over the United Nations Secretariat (or affinity between the Secretariat and the United States) has changed over time. The solid gray line (right axis) shows the share of senior positions in the Secretariat held by Americans. The solid black line (left axis) describes American influence over the Secretariat, as defined by Equation 2. The dashed black line (left axis) describes what American influence over the Secretariat would look like if the affinity between nations remained fixed at its 1950 level. The affinity measures are based on voting in the U.N. General Assembly. 


\section{Figure 6}

Secretariat bias toward USA

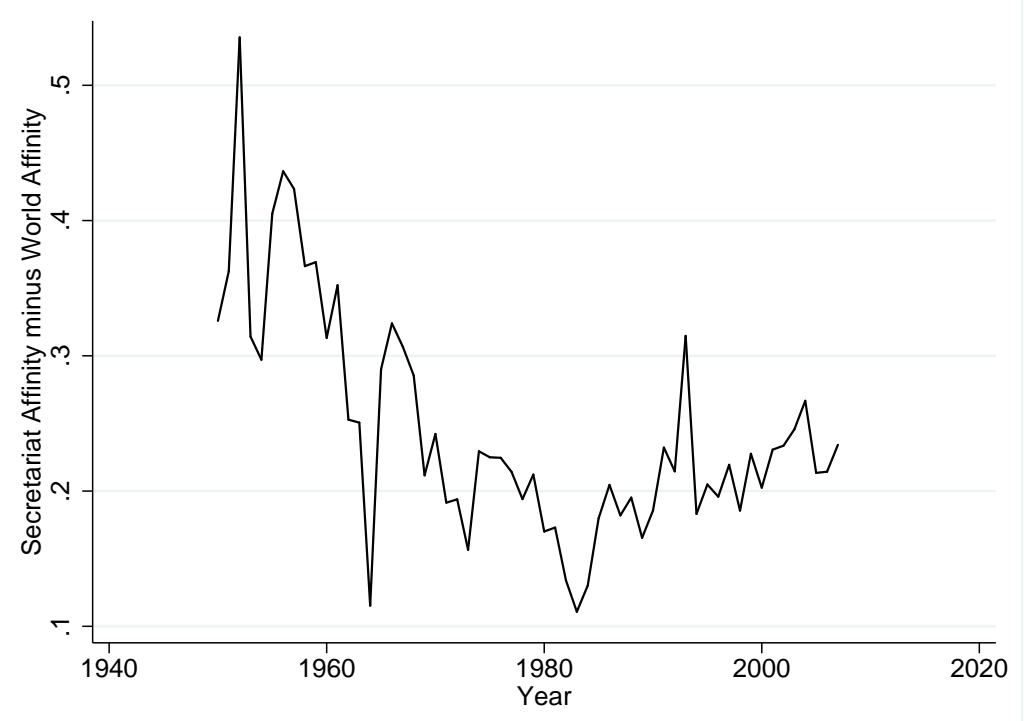

The graph shows the extent to which the staffing of the U.N. Secretariat is biased toward the United States. The y axis measures the difference in each year between the affinity of the world for the United States (based on population weighting) and the affinity of the U.N. Secretariat (based on staff positions) for the United States. 


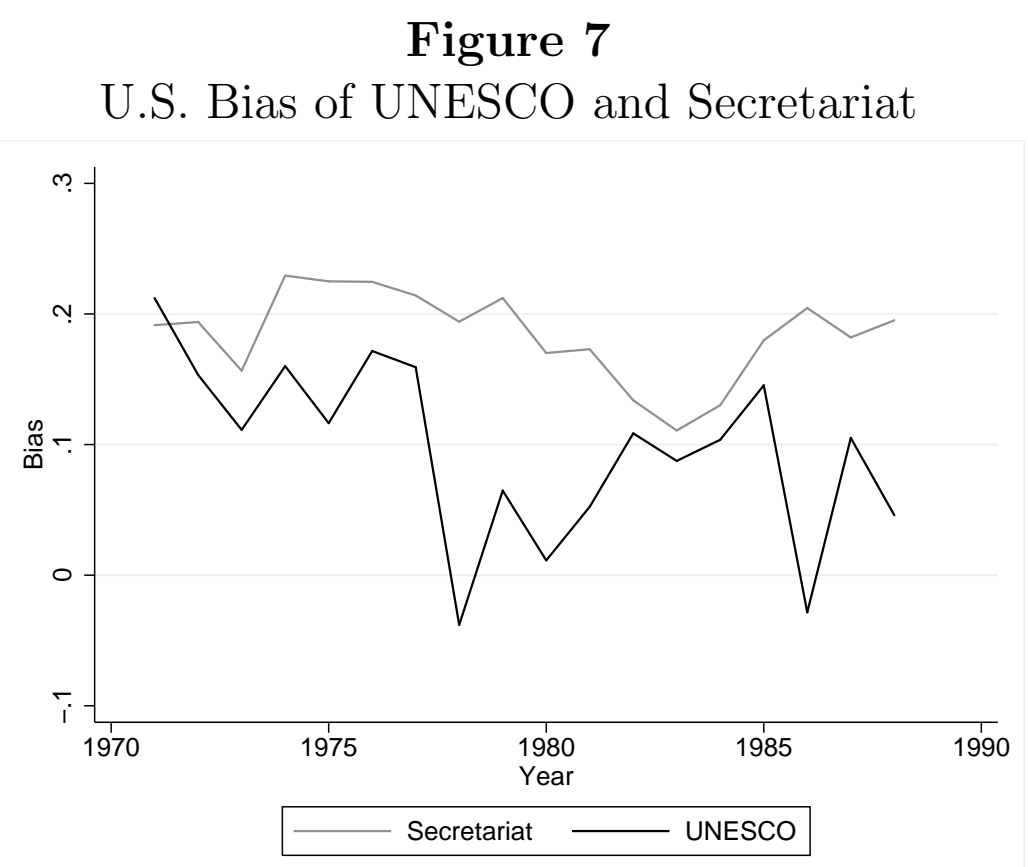

The graph shows the extent to which the staffing of UNESCO is biased toward the United States. The y axis measures the difference in each year between the affinity of the world for the United States (based on population weighting) and the affinity of UNESCO (based on staff positions) for the United States. 


\section{References}

Allen, Susan Hannah and Amy T. Yuen, "The Politics of Peacekeeping: UN Security Council Oversight Across Peacekeeping Missions," International Studies Quarterly, June 2013, pp. 1-12.

Ameri, Houshang, Politics of Staffing the United Nations Secretariat, New York: Peter Lang Publishing, 1996.

Ayer Co Publishers, "Who's Who in the United Nations and Related Agencies," 1975.

Bachrach, Peter and Morton S. Baratz, "Two Faces of Power," The American Political Science Review, 1962, 56 (4), 947-952.

Baldwin, David A., "Power and International Relations," in Walter Carsnaes, Thomas Risse, and Beth A. Simmons, eds., Handbook of International Relations, London: Sage Publications Ltd, 2013, pp. 273-97.

Barnett, Michael and Raymond Duvall, "Power in International Politics," International Organization, February 2005, 59, 39-75.

Barro, Robert J. and Jong Wha Lee, "A new data set of educational attainment in the world, 1950-2010," Journal of Development Economics, September 2012, 104, 184-198.

Burckel, Christian E., Who's Who in the United Nations, Christan E. Burckel \& Associates, 1951.

Cline, Ray S., World Power Assessment: A Calculus of Strategic Drift, Center for Strategic and International Studies, Georgetown University, 1975.

Dahl, Robert, "The Concept of Power," Behavioral Science, 1957, 2, 201-15.

Finger, Seymour Maxwell, The Politics of Staffing the United Nations Secretariat 1975.

_ , Your Man at the U.N., New York: NYU University Press, 1980.

and Nina Hanan, "The UN Secretariat Revisited," October 1980.

Fisman, Raymond and Edward Miguel, "Corruption, Norms, and Legal Enforcement: Evidence from Diplomatic Parking Tickets," Journal of Political Economy, 2007, 115 (6), 1020-1048.

Gartzke, Erik, "Kant We All Just Get Along? Opportunity, Willingness, and the Origins of the Democratic Peace," American Journal of Political Science, 1998, 42 (1), 1-27.

_ , "Affinity of Nations Index," 2006. 
George, Aurelia, "Japan's Participation in U.N. Peacekeeping Operations: Radical Departure or Predictable Response?," Asian Survey, 1993, 33 (6), 560-575.

Greenfield, Stanley, Who's Who in the United Nations and Related Agencies, Omnigraphics Incorporated, 1992.

Gulick, Edward, Europe's Classical Balance of Power, New York: W. W. Norton, 1955.

Guzzini, Stefano, "On the measure of power and the power of measure in International Relations," 2009.

, Power, Realism and Constructivism, New York: Routledge, 2013.

Harsanyi, John, "Measurement of Social Power, Opportunity Costs, and the Theory of Two-person Bargaining Games," Behavioral Science, 1962, 7, 67-80.

Ikenberry, GJ, "Getting hegemony right," National Interest, 2001.

Jacobson, Harold K., "U.S. Withdrawal From UNESCO: Incident, Warning, or Prelude?," $P S, 1984,17(3), 581-585$.

Johns, Leslie, "A Servant of Two Masters: Communication and the Selection of International Bureaucrats," International Organization, April 2007, 61 (02), 245-275.

Johnson, Tana, "Looking beyond States: Openings for international bureaucrats to enter the institutional design process," The Review of International Organizations, February 2013, 8 (4), 499-519.

Joyner, Christopher C. and Scott A. Lawson, "The United States and UNESCO: Rethinking the Decision to Withdraw," International Journal, 1986, 41 (1), 37-71.

Kagan, Robert, The World America Made, New York: Vintage, 2012.

Kaja, Ashwin and Eric Werker, "Corporate Governance at the World Bank and the Dilemma of Global Governance," The World Bank Economic Review, June 2010, 24 (2), 171-198.

Katzenstein, Peter J., Small States in World Markets: Industrial Policy in Europe, Cornell University Press, 1985.

Kaufmann, Daniel, Aart Kraay, and Massimo Mastruzzi, "Worldwide Governance Indicators," 2011.

Kelen, Emery, Hammarskjold, The Political Man, New York: Funk and Wagnalls, 1968.

Kennedy, Paul M., The Rise and Fall of the Great Powers, New York: Vintage, 1989.

Keohane, Robert, After Hegemony, Princeton: Princeton University Press, 1984. 
Kilby, Christopher, "Informal influence in the Asian Development Bank," Review of International Organizations, 2011, 6, 223-257.

Kleine, Mareike, "Trading control: national fiefdoms in international organizations," International Theory, November 2013, 5 (03), 321-346.

Kuziemko, Ilyana and Eric Werker, "How Much Is a Seat on the Security Council Worth? Foreign Aid and Bribery at the United Nations," Journal of Political Economy, 2006, 114 (5), 905-930.

Lieber, Robert J., Power and Willpower in the American Future: Why the United States is not Destined to Decline, New York: Cambridge University Press, 2012.

Lim, Daniel Yew Mao and James Raymond Vreeland, "Regional Organizations and International Politics: Japanese Influence over the Asian Development Bank and the UN Security Council," World Politics, January 2013, 65 (01), 34-72.

Lukes, Steven, Power: A Radical View, New York: MacMillan, 1974.

Marshall, Monty G. and Keith Jaggers, "Polity IV Project: Political Regime Characteristics and Transitions, 1800-2002," 2002.

Mearsheimer, John J, "The False Promise of International Institutions," International Security, 1994, 19 (3), 5-49.

Meron, Theodor, "Charter Powers of the United Nations' Secretary-General with regard to the Secretariat and the Role of General Assembly Resolutions," Heidelberg Journal of International Law, 1982, 42.

Morgenthau, Hans, Politics Among Nations,, New York: Alfred A. Knopf, 1948.

Mosser, MW, "Engineering Influence: The Subtile Power of Small States in the CSCE/OSCE," 2000.

Nexon, Daniel H. and Thomas Wright, "What's at Stake in the American Empire Debate," American Political Science Review, May 2007, 101 (02), 253-271.

Nye, Joseph S., "The Decline and Fall of America's Decline and Fall," 2011. , The Future of Power, New York: Public Affairs, 2011.

Pevehouse, Jon C., Timothy Nordstrom, and Kevin Warnke, "The COW-2 International Organizations Dataset Version 2.0," Conflict Management and Peace Science, 2004, 21 (2).

Puchala, Donald J., "Hope and Folly: The United States and UNESCO 1945-1985. by William Preston, Edward Herman and Herbert Schiller," Political Science Quarterly, 1990, 105 (3), 497-498. 
Reymond, Henri, "The Staffing of the United Nations Secretariat: A Continuing Discussion," International Organization, 1967, 21 (4), 751-767.

Rhamey, Patrick, Kirssa Cline, Sverre Bodung, Alexis Henshaw, Beau James, Chansuk Kang, Alicia Sedziak, Aakriti Tandon, and Thomas J. Volgy, "Diplomatic Contacts Database (DIPCON) v1.1," 2010.

Robert, Cox and Harold Jacobson, The Anatomy of Influence: Decision-making in International Organizations, New Haven: Yale University Press, 1973.

Rodrik, Dani, "Why Do More Open Economies Have Bigger Governments ?," Journal of Political Economy, 2014, 106 (5), 997-1032.

Rubenfeld, Jed, "Unilateralism and constitutionalism," New York University Law Review, 2004, 79 (6).

Singer, J. David, "Reconstructing the Correlates of War Dataset on Material Capabilities of States, 1816-1985," International Interactions, 1987, 14, 115-32.

Stone, Randall W., "The Political Economy of IMF Lending in Africa," The American Political Science Review, 2004, 98 (4), 577-591.

Tellis, Ashley J., Janice Bially, Christopher Layne, and Melissa McPherson, Measuring National Power in the Postindustrial Age, Santa Monica: RAND Corporation, 2000.

Thant, Myint-U and Amy Scott, The UN Secretariat: A Brief History, New York: International Peace Academy, 2007.

The Economist, "A Case for Emergency Treatment," December 21989.

Turner, Mark, "U.N. chief gives out top jobs," Financial Times, February 92007.

United Nations, "Charter of the United Nations," 1945.

, Yearbook of the United Nations 1947.

, "Composition of the Secretariat: Demographics," Technical Report, United Nations Secretary-General 2012.

United States Senate, "Soviet Presence in the U.N. Secretariat," Technical Report May, Senate Select Comittee on Intelligence, United States Senate, Washington 1985.

Urpelainen, Johannes, "Unilateral Influence on International Bureaucrats: An International Delegation Problem," Journal of Conflict Resolution, 2012, 56 (4), 704-35.

Voeten, Erik, "Data and Analyses of Voting in the United Nations General Assembly," in Robert Reinalda, ed., Routledge Handbook of International Organizations, Routledge, 2013, pp. 54-66. 
Watt, Nicholas, "Lady Amos given top UN humanitarian affairs job," July 2010.

Wynes, M Deborah and Mohamed Mounir Zahran, "Transparency in the Selection and Appointment of Senior Managers in the United Nations Secretariat," Technical Report, United Nations: Joint Inspection Unit, Geneva 2011. 


\section{A Appendix}

Table A1

Secretariat representation, average share over all years

\begin{tabular}{|c|c|c|}
\hline$\overline{\text { Rank }}$ & Country & Share of positions \\
\hline 1 & United States & 0.1292 \\
\hline 2 & United Kingdom & 0.0581 \\
\hline 3 & India & 0.0447 \\
\hline 4 & Sweden & 0.0428 \\
\hline 5 & Canada & 0.0382 \\
\hline 6 & France & 0.0343 \\
\hline 7 & Italy & 0.0264 \\
\hline 8 & Pakistan & 0.0259 \\
\hline 9 & Russian Federation & 0.0237 \\
\hline 10 & Argentina & 0.0224 \\
\hline 12 & Finland & 0.0206 \\
\hline 13 & Japan & 0.0206 \\
\hline 14 & Norway & 0.0180 \\
\hline 15 & Ghana & 0.0178 \\
\hline 16 & Egypt & 0.0173 \\
\hline 17 & Chile & 0.0161 \\
\hline 18 & Germany & 0.0158 \\
\hline 19 & Australia & 0.0150 \\
\hline 20 & Denmark & 0.0150 \\
\hline 21 & Greece & 0.0149 \\
\hline 22 & Netherlands & 0.0146 \\
\hline 23 & Nigeria & 0.0131 \\
\hline 24 & Brazil & 0.0131 \\
\hline 25 & Sri Lanka & 0.0125 \\
\hline 26 & Taiwan & 0.0122 \\
\hline 27 & Switzerland & 0.0118 \\
\hline 28 & Austria & 0.0117 \\
\hline 29 & New Zealand & 0.0114 \\
\hline 30 & Ireland & 0.0109 \\
\hline 31 & Poland & 0.0100 \\
\hline 32 & Mexico & 0.0091 \\
\hline 33 & Peru & 0.0091 \\
\hline 34 & China & 0.0086 \\
\hline 35 & Philippines & 0.0085 \\
\hline 36 & Myanmar & 0.0085 \\
\hline 37 & Tunisia & 0.0083 \\
\hline
\end{tabular}


Table A1

Secretariat representation, average share over all years

\begin{tabular}{rrr}
\hline Rank & Country & Share of positions \\
\hline 38 & Colombia & 0.0082 \\
39 & Iran & 0.0072 \\
40 & Algeria & 0.0071 \\
41 & Belgium & 0.0070 \\
\hline 42 & Senegal & 0.0068 \\
43 & Czech Republic & 0.0067 \\
44 & Venezuela & 0.0065 \\
45 & South Africa & 0.0060 \\
46 & Sierra Leone & 0.0056 \\
\hline 47 & Cameroon & 0.0055 \\
48 & Indonesia & 0.0055 \\
49 & Uruguay & 0.0053 \\
50 & Burundi & 0.0052 \\
51 & Panama & 0.0050 \\
\hline 52 & Niger & 0.0050 \\
53 & Spain & 0.0048 \\
54 & Guatemala & 0.0048 \\
55 & Iraq & 0.0047 \\
56 & Jamaica & 0.0047 \\
\hline 57 & Somalia & 0.0047 \\
58 & Turkey & 0.0045 \\
59 & Jordan & 0.0037 \\
60 & Ecuador & 0.0037 \\
61 & Malaysia & 0.0036 \\
\hline 62 & Yemen & 0.0035 \\
63 & Korea, Rep. & 0.0034 \\
64 & Bangladesh & 0.0032 \\
65 & Burkina Faso & 0.0032 \\
66 & Sudan & 0.0030 \\
\hline 67 & Hungary & 0.0029 \\
68 & Tanzania & 0.0029 \\
69 & Nepal & 0.0028 \\
70 & Haiti & 0.0028 \\
71 & Costa Rica & 0.0021 \\
\hline 72 & Syria & 0.0020 \\
73 & Mgandi & 0.0020 \\
74 & & 0.0018 \\
75 & 0.0017 \\
\hline &
\end{tabular}


Table A1

Secretariat representation, average share over all years

\begin{tabular}{rrr}
\hline Rank & Country & Share of positions \\
\hline 76 & Portugal & 0.0016 \\
\hline 77 & Bolivia & 0.0015 \\
78 & Botswana & 0.0015 \\
79 & Bulgaria & 0.0014 \\
80 & Saudi Arabia & 0.0013 \\
81 & Kenya & 0.0012 \\
\hline 82 & Slovak Republic & 0.0012 \\
83 & Guinea & 0.0012 \\
84 & Cuba & 0.0012 \\
85 & Zimbabwe & 0.0011 \\
86 & Lebanon & 0.0010 \\
\hline 87 & Namibia & 0.0009 \\
88 & Liberia & 0.0008 \\
89 & Thailand & 0.0008 \\
90 & El Salvador & 0.0007 \\
91 & Togo & 0.0005 \\
\hline 92 & Ethiopia & 0.0005 \\
93 & Chad & 0.0003 \\
94 & Eritrea & 0.0003 \\
95 & Lesotho & 0.0002 \\
96 & Mozambique & 0.0002 \\
\hline 97 & Afghanistan & 0.0000 \\
97 & Angola & 0.0000 \\
97 & Albania & 0.0000 \\
97 & United Arab Emirates & 0.0000 \\
97 & Armenia & 0.0000 \\
\hline 97 & Azerbaijan & 0.0000 \\
97 & Benin & 0.0000 \\
97 & Bosnia And Herzegovina & 0.0000 \\
97 & Belarus & 0.0000 \\
97 & Central African Republic & 0.0000 \\
\hline 97 & Cote D'Ivoire & 0.0000 \\
97 & Congo, Rep. & 0.0000 \\
97 & Estonia & 0.0000 \\
97 & Georgia & 0.0000 \\
97 & Honduras & 0.0000 \\
\hline 97 & Croatia & 0.0000 \\
97 & & 0.0000 \\
\hline &
\end{tabular}


Table A1

Secretariat representation, average share over all years

\begin{tabular}{rrr}
\hline Rank & Country & Share of positions \\
\hline 97 & Israel & 0.0000 \\
97 & Kazakhstan & 0.0000 \\
97 & Kyrgyz Republic & 0.0000 \\
\hline 97 & Cambodia & 0.0000 \\
97 & Kosovo & 0.0000 \\
97 & Kuwait & 0.0000 \\
97 & Laos & 0.0000 \\
97 & Libya & 0.0000 \\
\hline 97 & Lithuania & 0.0000 \\
97 & Latvia & 0.0000 \\
97 & Morocco & 0.0000 \\
97 & Moldova & 0.0000 \\
97 & Madagascar & 0.0000 \\
\hline 97 & Macedonia & 0.0000 \\
97 & Mongolia & 0.0000 \\
97 & Mauritania & 0.0000 \\
97 & Malawi & 0.0000 \\
97 & Nicaragua & 0.0000 \\
\hline 97 & Oman & 0.0000 \\
97 & Papua New Guinea & 0.0000 \\
97 & Puerto Rico & 0.0000 \\
97 & Korea, Dem. Rep. & 0.0000 \\
97 & Paraguay & 0.0000 \\
\hline 97 & Romania & 0.0000 \\
97 & Rwanda & 0.0000 \\
97 & Serbia & 0.0000 \\
97 & Slovenia & 0.0000 \\
97 & Tajikistan & 0.0000 \\
\hline 97 & Turkmenistan & 0.0000 \\
97 & Trinidad And Tobago & 0.0000 \\
97 & Ukraine & 0.0000 \\
97 & Uzbekistan & 0.0000 \\
97 & Vietnam & 0.0000 \\
\hline 97 & West Bank And Gaza & 0.0000 \\
97 & Congo, Dem. Rep. & 0.0000 \\
97 & Zambia & 0.0000 \\
\hline & & \\
\hline
\end{tabular}




\section{Table A2}

More correlates of U.N. secretariat representation COUNTRY F.E.

\begin{tabular}{lcccc}
\hline \hline & $(1)$ & $(2)$ & $(3)$ & $(4)$ \\
\hline Population share & 0.327 & -0.255 & 0.357 & -0.224 \\
Inverse corruption (rescaled) & $(0.898)$ & $(1.015)$ & $(1.187)$ & $(0.884)$ \\
& 0.000 & 0.001 & 0.001 & 0.000 \\
GDP Per Capita (rescaled) & $0.001)$ & $(0.002)$ & $(0.001)$ & $(0.002)$ \\
& $(0.002)$ & 0.004 & 0.005 & 0.002 \\
Diplomatic contacts (share) & 0.250 & 0.197 & 0.513 & 0.166 \\
& $(0.357)$ & $(0.334)$ & $(0.496)$ & $(0.294)$ \\
Democracy (Polity, rescaled) & -0.000 & -0.000 & -0.000 & -0.000 \\
& $(0.001)$ & $(0.001)$ & $(0.001)$ & $(0.001)$ \\
UN Fee Assessment & 0.494 & & & 0.233 \\
Human capital share & $(0.238)^{* *}$ & & & $(0.160)$ \\
& & 0.430 & & 0.383 \\
Military spending share & & $(0.135)^{* * *}$ & & $(0.186)^{* *}$ \\
& & & 0.080 & 0.124 \\
Constant & & & $(0.034)^{* *}$ & $(0.100)$ \\
& 0.002 & 0.006 & 0.001 & 0.005 \\
$\mathrm{~N}$ & $(0.007)$ & $(0.005)$ & $(0.009)$ & $(0.005)$ \\
$\mathrm{r} 2$ & 5023 & 4615 & 4937 & 4552 \\
${ }^{*} p<0.10{ }^{* *} p<0.05,{ }^{* * *} p<0.01$ & 0.68 & 0.68 & 0.69 \\
\hline
\end{tabular}

